Enefronmented

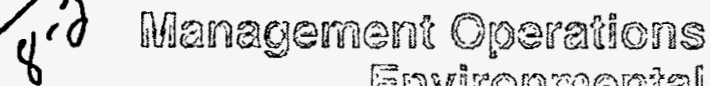

BigyironTughted Thanemen Oy

Environinerger Mangemen Oraratons

[Emetronmente?

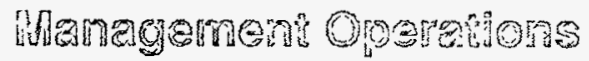
Environmental Management Operations Environmental Management Operations Environmental Management Operations

Emvirommen? Manegentent orerritens

EnV:ron Manogerment Onandions

Environnemta? Menogemen? Orargengs Engnronumensed

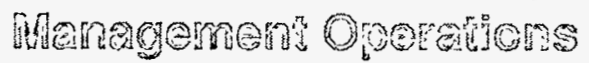

[Emironmence] mangenen Operanoms

[Engironmen: nanogemen Operathons

Envison:men?

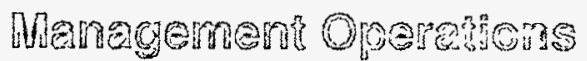

Environnenus] nhangenen Operainons

Ervymonmenga Mraneyemen Oreramons

Bnvironmen?

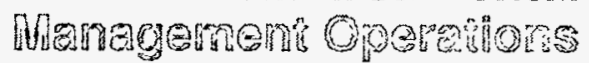

\section{Surveillance of Site A and Plot M Report for 1995}

\author{
by N. W. Golchert
}


Argonne National Laboratory, with facilities in the states of Illinois and Idaho, is owned by the United States government, and operated by The University of Chicago under the provisions of a contract with the Department of Energy.

\section{DISCLAIMER}

This report was prepared as an account of work sponsored by an agency of the United States Government. Neither the United States Government nor any agency thereof, nor any of their employees, makes any warranty, express or implied, or assumes any legal liability or responsibility for the accuracy, completeness, or usefulness of any information, apparatus, product, or process disclosed, or represents that its use would not infringe privately owned rights. Reference herein to any specific commercial product, process, or service by trade name, trademark, manufacturer, or otherwise, does not necessarily constitute or imply its endorsement, recommendation, or favoring by the United States Government or any agency thereof. The views and opinions of authors expressed herein do not necessarily state or reflect those of the United States Government or any agency thereof.

Reproduced from the best available copy.

Available to DOE and DOE contractors from the

Office of Scientific and Technical Information

P.O. Box 62

Oak Ridge, TN 37831

Prices available from (423) 576-8401

Available to the public from the

National Technical Information Service

U.S. Department of Commerce

5285 Port Royal Road

Springfield, VA 22161 
Distribution Category:

Remedial Action

Decommissioning Program

(UC-511)

ANL-96/2

\section{ARGONNE NATIONAL LABORATORY \\ 9700 South Cass Avenue \\ Argonne, Illinois 60439}

SURVEILLANCE OF SITE A AND PLOT M

Report for 1995

by

Norbert W. Golchert

Environmental Management Operations

June 1996

DISTRIBUTION OF THIS DOCUMENT IS UNLIMITED

Prepared for the U. S. Department of Energy 


\section{DISCLAIMER}

Portions of this document may be illegible in electronic image products. Images are produced from the best available original document. 
ABSTRACT $\ldots \ldots \ldots \ldots \ldots \ldots \ldots \ldots \ldots \ldots \ldots \ldots \ldots$

1.0 INTRODUCTION AND MONITORING $\ldots \ldots \ldots \ldots \ldots \ldots \ldots$

1.1 Site History $\ldots \ldots \ldots \ldots \ldots \ldots \ldots \ldots \ldots \ldots \ldots \ldots \ldots \ldots \ldots$

1.2 Site Characteristics $\ldots \ldots \ldots \ldots \ldots \ldots \ldots \ldots \ldots \ldots$

2.0 SUMMARY $\ldots \ldots \ldots \ldots \ldots \ldots \ldots \ldots \ldots \ldots \ldots \ldots$

3.0 MONITORING PROGRAM $\ldots \ldots \ldots \ldots \ldots \ldots \ldots \ldots \ldots \ldots$

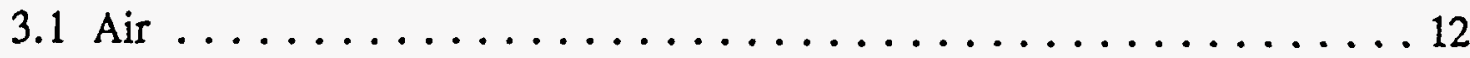

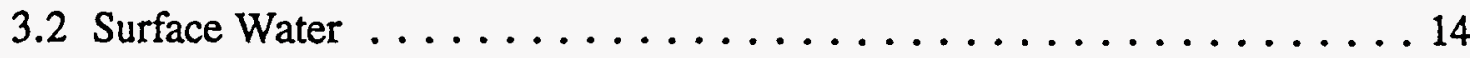

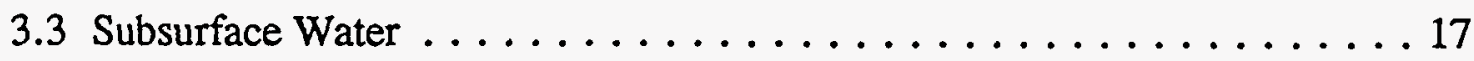

3.3.1 Borehole Water - Plot $\mathrm{M} \ldots \ldots \ldots \ldots \ldots$

3.3.2 Borehole Water - Site A . . . . . . . . . . . 31

3.3.3 Dolomite Hole Water $\ldots \ldots \ldots \ldots \ldots \ldots \ldots \ldots$

3.3 .4 Well Water $\ldots \ldots \ldots \ldots \ldots \ldots \ldots \ldots \ldots \ldots \ldots$

3.4 Bottom Sediment $\ldots \ldots \ldots \ldots \ldots \ldots \ldots \ldots \ldots \ldots \ldots$. . . . . . . . . . . . .

4.0 SUMMARY OF POTENTIAL RADIATION DOSE AND RISK ESTIMATES $\ldots \ldots \ldots \ldots \ldots \ldots \ldots \ldots \ldots \ldots \ldots \ldots \ldots \ldots$

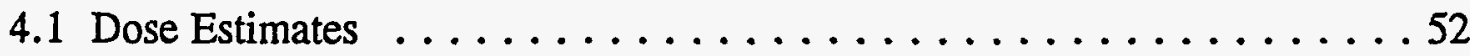

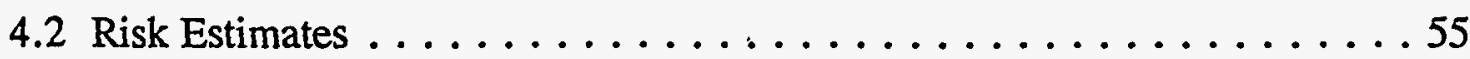

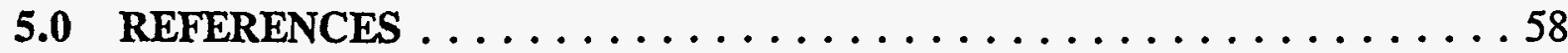

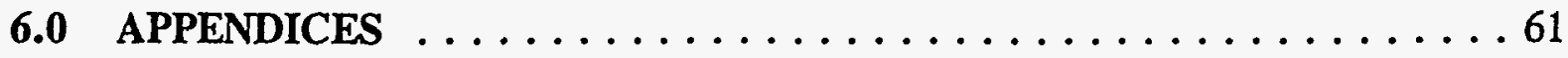

6.1 Quality Assurance Program $\ldots \ldots \ldots \ldots \ldots \ldots \ldots \ldots \ldots$

6.2 Applicable Standards . . . . . . . . . . . . . . . . . 62

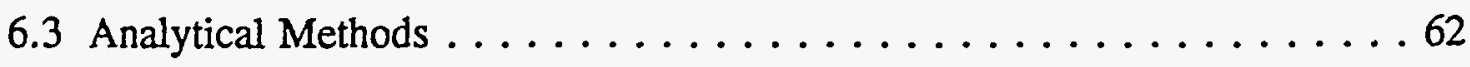

6.4 Acknowledgments $\ldots \ldots \ldots \ldots \ldots \ldots \ldots \ldots \ldots \ldots \ldots \ldots \ldots \ldots \ldots \ldots$ 


\section{LIST OF TABLES}

Page

2.1 Annual Maximum and Average Hydrogen-3 Concentrations in the Red Gate Woods Wells . . . . . . . . . . . . . . . . . . . . . 10

3.1 Concentrations of Tritiated Water Vapor Above the Streambed Adjacent to Plot M, $1995 \ldots \ldots \ldots \ldots$. . . . . . . . . 13

3.2 Tritiated Water Content of Stream Next to Plot M, 1995 . . . . . . . . . . . 16

3.3 Radioactivity Content of Stream Next to Plot M, 1995 . . . . . . . . . . . 18

3.4 Tritium in Borehole Water, $1995 \ldots \ldots \ldots \ldots \ldots \ldots$

3.5 Water Level Measurements in Boreholes Near

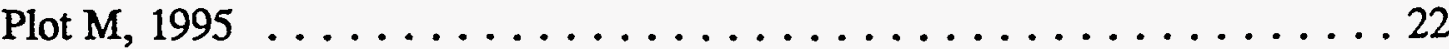

3.6 Radiochemical Analysis of Borehole Water Samples Near Plot M, 1995 . . . . . . . . . . . . . . . . . . . . . . . . 30

3.7 Tritium in Site A Borehole Water, $1995 \ldots \ldots \ldots \ldots$

3.8 Water Level Measurements in Boreholes Near

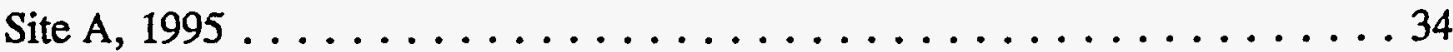

3.9 Radiochemical Analysis of Borehole Water Samples

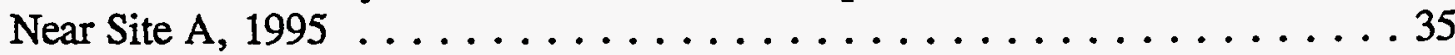

3.10 Tritium in Site A Dolomite Holes, 1995 . . . . . . . . . . . . . . . 38

3.11 Water Level Measurements in Dolomite Holes, 1995 . . . . . . . . . . . . . . . 39

3.12 Tritiated Water Content of Wells Near Site A/Plot M, 1995 . . . . . . . . . . 44

3.13 Uranium Content of Well Water Near Plot M, 1995 . . . . . . . . . . . . . 48

3.14 Inorganic Constituents in Red Gate Woods North Well Water $(\# 5160), 1995 \ldots \ldots \ldots$. . . . . . . . . . . . . . . 50

3.15 Radioactivity Content of Streambed Next to Plot M, 1995 . . . . . . . . . 51

4.1 Dose From Continuous Exposure to Tritium at Selected Locations, 1995 . . . . . . . . . . . . . . . . . . . . . 53

4.2 Estimates of Tritium Exposures to a Casual Visitor to Plot M, 1995 . . . . . 54

4.3 Annual Average Dose Equivalent in the U. S. Population . . . . . . . . . 56

4.4 Risk of Death From Natural Events . . . . . . . . . . . . . . . . 57 


\section{LIST OF FIGURES}

Page

1.1 Location of Palos Forest Preserve on Chicago-Area Map . . . . . . . . 4

1.2 Palos Forest Preserve Showing Location of Site A/Plot M

Dolomite Holes and Picnic Wells . . . . . . . . . . . . . . . 5

2.1 Trends in Tritium Concentrations in Red Gate Woods

Well (\#5167) . . . . . . . . . . . . . . . . . . . 10

3.1 Surface Water Sampling Locations Near Plot $M \ldots \ldots \ldots \ldots$

3.2 Map of Plot M Palos Site Showing Topography,

Intermittent Stream, and Borehole Locations . . . . . . . . . . . 19

3.3 Subsurface Tritium Contours From the February 1995 Samples . . . . . . 23

3.4 Subsurface Tritium Contours From the April 1995 Samples . . . . . . . . . . 24

3.5 Subsurface Tritium Contours From the June 1995 Samples . . . . . . . . . . 25

3.6 Subsurface Tritium Contours From the August 1995 Samples . . . . . . . . 26

3.7 Subsurface Tritium Contours From the October 1995 Samples . . . . . . . 27

3.8 Subsurface Tritium Contours From the December 1995 Samples . . . . . . . 28

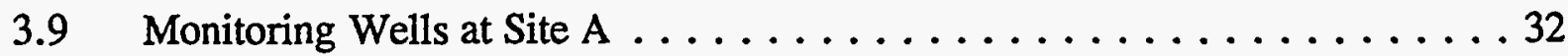

3.10 Locations of Dolomite Holes North of Plot M . . . . . . . . . . . 37

3.11 Tritium Concentrations in DH15, 1987-1995 . . . . . . . . . . . 42

3.12 Tritiated Water Concentrations in Red Gate Woods (\#5167), Opposite Red Gate Woods (\#5159), and Red Gate Woods North (\#5160) Wells From 1990 Through 1995 . . . . . . . . . . . . . . 46 


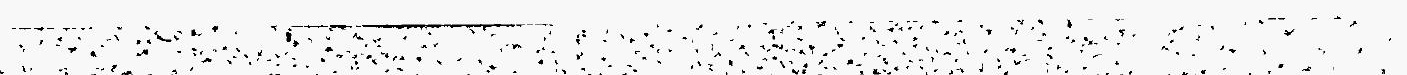




\section{SURVEILLANCE OF SITE A AND PLOT M}

Report for 1995

by

N. W. Golchert

\section{ABSTRACT}

The results of the environmental surveillance program conducted at Site A/Plot $M$ in the Palos Forest Preserve area for 1995 are presented. The surveillance program is the ongoing remedial action that resulted from the 1976-1978 radiological characterization of the site. That study determined that very low levels of hydrogen-3 (as tritiated water) had migrated from the burial ground and were present in two nearby hand-pumped picnic wells. The current program consists of sample collection and analysis of air, surface and subsurface water, and bottom sediment. The results of the analyses are used to 1) monitor the migration pathway of water from the burial ground (Plot M) to the hand-pumped picnic wells, 2) establish if buried radionuclides other than hydrogen-3 have migrated, and 3) generally characterize the radiological environment of the area. Hydrogen-3 in the Red Gate Woods picnic wells was still detected this year, but the average and maximum concentrations were significantly less than found earlier. Tritiated water continues to be detected in a number of wells, boreholes, dolomite holes, and a surface stream. For many years it was the only radionuclide found to have migrated in measurable quantities. Analyses since 1984 have indicated the presence of low levels of strontium- 90 in water from a number of boreholes next to Plot $\mathrm{M}$. The available data does not allow a firm conclusion as to whether the presence of this nuclide represents recent migration or movement that may have occurred before Plot $M$ was capped. The results of the surveillance program continue to indicate that the radioactivity remaining at Site $\mathrm{A} / \mathrm{Plot} \mathrm{M}$ does not endanger the health or safety of the public visiting the site, using the picnic area, or living in the vicinity. 


\subsection{INTRODUCTION AND MONITORING}

\subsection{Site History}

This report presents and discusses the surveillance data obtained during 1995. The surveillance program is the ongoing remedial action that resulted from the 1976-1978 radiological characterization of the former site of Argonne National Laboratory and its predecessor, the University of Chicago's Metallurgical Laboratory, which was part of the World War II Manhattan Engineer District Project, in the Palos Forest Preserve southwest of Chicago, IL. The Laboratory used two locations in the Palos Forest Preserve: Site A, a 19-acre area that contained experimental laboratories and nuclear reactor facilities; and Plot M, a $150 \mathrm{ft}$ $\mathrm{x} 140 \mathrm{ft}$ area used for the burial of radioactive waste. These locations are shown in Figures 1.1 and 1.2. To assist in understanding this report, reference should be made to the previous comprehensive reports on this subject, ${ }^{1,2}$ which provide greater detail and illustrations on sampling locations and descriptive material and give the results through 1981, and to the annual reports for 1982 through $1994 .^{3-15}$ Earlier data will not be repeated in this report, but reference will be made to some of the results.

Operations at Site A began in 1943 and ceased in 1954. Among the research programs carried out at Site A were reactor physics studies, fission product separations, tritium recovery from irradiated lithium, and studies of the metabolism of radionuclides in laboratory animals. Radioactive waste and radioactively-contaminated laboratory articles from these studies were buried in Plot M. At the termination of the programs, the reactor fuel and heavy water, used for neutron moderation and reactor cooling, were removed and shipped to Oak Ridge National Laboratory. The biological shield for the CP-3 reactor, together with various pipes, valves, and building debris, was buried in place in 1956.

Burial of radioactive waste at Plot M began in 1943 or 1944 and was discontinued in 1949. Waste was buried in six-foot deep trenches and covered with soil until 1948, after 


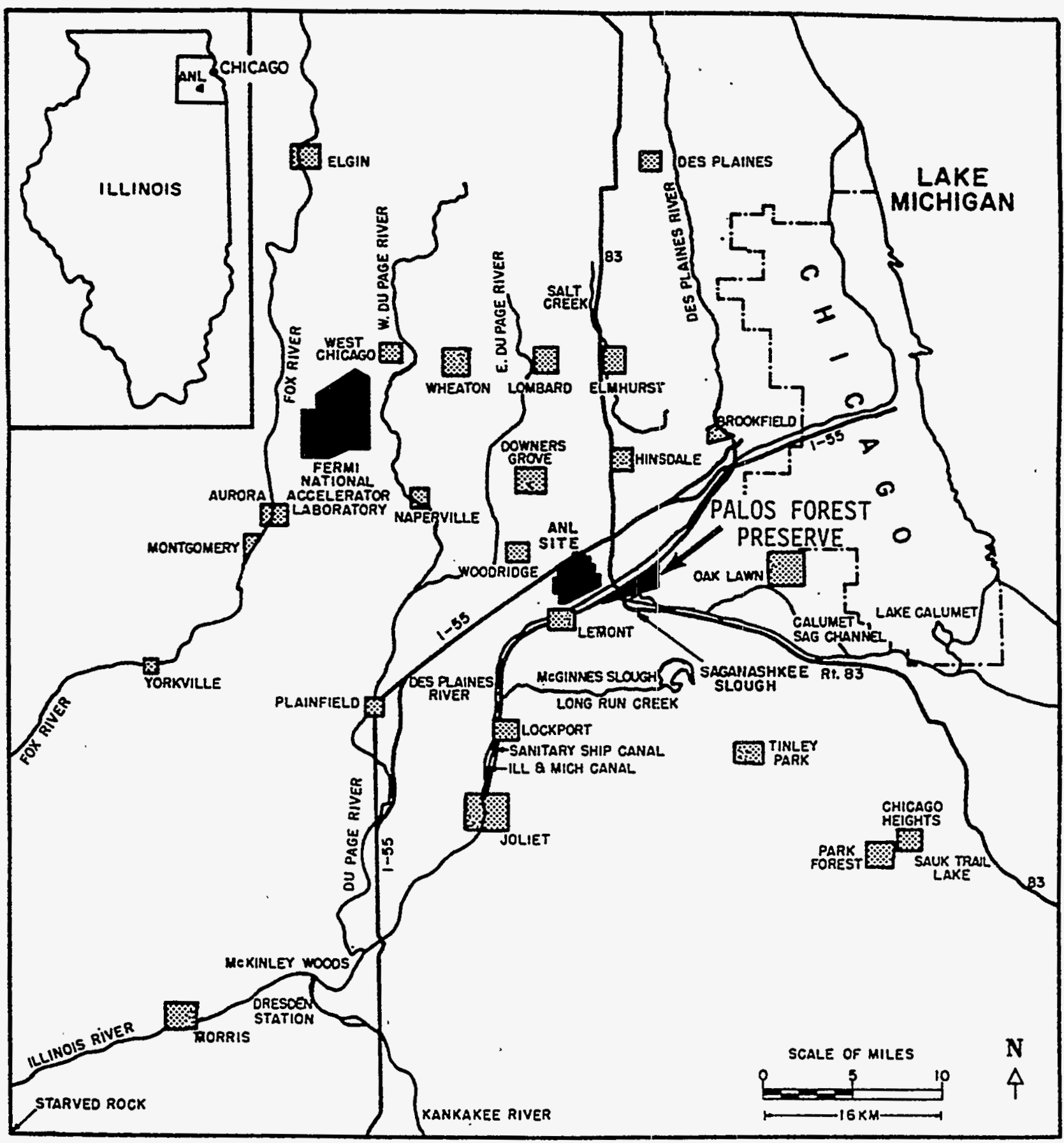

Figure 1.1 Location of Palos Forest Preserve on Chicago-Area Map 


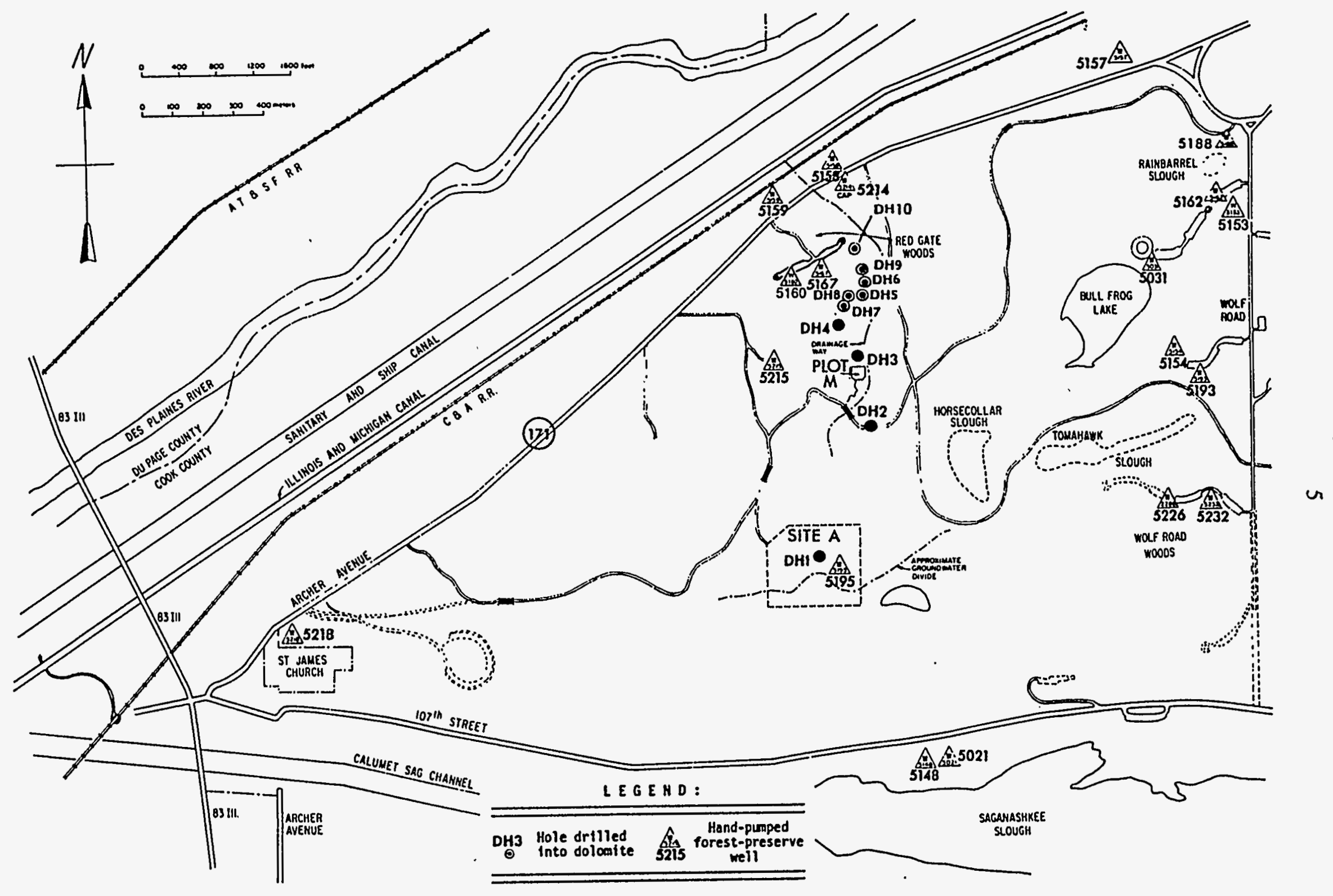

Figure 1.2 Palos Forest Preserve Showing Location of Site A/Plot M Dolomite Holes and Picnic Wells 
which, burial took place in steel bins. The steel bins were removed in 1949 and sent to Oak Ridge National Laboratory for disposal, but the waste buried in trenches was allowed to remain in place. Both the Site A and Plot M areas were decommissioned in 1956. Concrete sidewalls, eight feet deep, were poured around the perimeter of the burial area and a one-foot thick reinforced concrete slab was poured over the top. The concrete slab was covered with soil and seeded with grass.

In 1973, elevated levels of hydrogen-3 (as tritiated water) were detected in two nearby hand-pumped picnic wells (\#5167 and \#5159) and the hydrogen-3 was found to be migrating from the burial plot into the surrounding soil and aquifers. As a result, a radiological survey of the entire Palos Forest Preserve site was conducted with special emphasis on the Site A and Plot $\mathrm{M}$ areas. ${ }^{1}$

The terminology used in previous reports is continued. A hole drilled and completed into the glacial till is called a borehole. The soil samples obtained from the borehole are called soil cores. Some boreholes have been cased and screened to form monitoring wells. Water from such wells is called groundwater. Test wells drilled into the dolomite bedrock are called dolomite holes or deep holes. Water from such wells is called dolomite water. The hand-pumped picnic wells, which are completed into or close to the dolomite bedrock, are called water wells or picnic wells. They are identified by a location name or well number. Except for well $\# 5160$, these were in existence before this radiological and hydrological study of the area was begun.

The results of radioactivity measurements are expressed in this report in terms of picocuries per liter $(\mathrm{pCi} / \mathrm{L})$ and nanocuries per liter $(\mathrm{nCi} / \mathrm{L})$ for water, picocuries per cubic meter $\left(\mathrm{pCi} / \mathrm{m}^{3}\right)$ for air, and picocuries per gram $(\mathrm{pCi} / \mathrm{g})$ of the oven-dried $\left(110^{\circ} \mathrm{C}\right)$ weight for sediment samples. Radiation effective dose equivalent calculations are reported in units of millirem (mrem) or millirem per year (mrem/y). The use of the term dose throughout this report means effective dose equivalent. Other abbreviations of units are defined in the text. 


\subsection{Site Characteristics}

Geologically, Plot M is constructed on a moraine upland which is dissected by two valleys, the Des Plaines River valley to the north and the Calumet Sag valley to the south. The upland is characterized by rolling terrain with poorly developed drainage. Streams are intermittent and drain internally or flow to one of the valleys. The area is underlain by glacial till or drift, dolomite, and other sedimentary rocks. The uppermost bedrock is Silurian dolomite, into which both the picnic wells and some of the monitoring wells are placed, as described in the text. The dolomite bedrock is about 200 feet thick. The overlying glacial till has a thickness that ranges from 165 feet at Site A to zero at the Des Plaines River and Calumet Sag Canal, and some of the monitoring wells terminate in this layer. The depth to bedrock at Plot $M$ is about 130 feet. Hydrologically, the surface water consists of ponds and intermittent streams. When there is sufficient water, the intermittent stream that drains Plot $M$ flows from the highest point near Site A, past Plot $M$, then continues near the Red Gate Woods well (Figure 1.2) and discharges into the Illinois and Michigan Canal. The groundwater in the glacial till and dolomite forms two distinct flow systems. The flow in the drift is controlled principally by topography. The flow in the dolomite, which is rechárged by groundwater from the glacial till, is controlled by two discharge areas, the Des

Plaines River to the north and the Calumet Sag Canal to the south. Water usage in the area is confined to the hand-pumped picnic wells. These are open to the dolomite and are principally used in the warmer seasons.

The climate is that of the upper Mississippi Valley, as moderated by Lake Michigan, and is characterized by cold winters and hot summers. Precipitation averages about 33 inches annually. The largest rainfalls occur between April and September. The average monthly temperature ranges from $21^{\circ} \mathrm{F}$ in January to $73^{\circ} \mathrm{F}$ in July. Approximately 7.9 million people reside within 50 miles of the site; the population within a five-mile radius is about 150,000. The only portion of the Palos Forest Preserve in the immediate area of Plot $\mathrm{M}$ and Site $\mathrm{A}$ that is developed for public use is the Red Gate Woods picnic area (Figure 1.2), 
although small numbers of individuals use the more remote areas of the Palos Forest Preserve.

\subsection{SUMMARY}

The results of the ongoing environmental monitoring and surveillance program at the Palos Forest Preserve site for 1995 are presented in this report. Sample collection and analyses for radioactive substances were conducted on air, surface and subsurface water, and bottom sediment, and for nonradioactive substances in subsurface water. Water-vapor samples were collected over the streambed at two locations, one upstream and one downstream of the waste buried at Plot M, and analyzed for tritium. Above ambient tritium concentrations were found downstream of the Plot and are attributed to tritiated water leaching from the Plot and evaporating from the stream. The maximum dose from tritium in air to a hypothetical individual who spends all of his time at the downstream location would be $0.02 \mathrm{mrem} / \mathrm{y}$, or $0.02 \%$ of the applicable U. S. Department of Energy (DOE) Radiation Protection Standard of $100 \mathrm{mrem} / \mathrm{y}$ for the general public. ${ }^{16}$

Surface water samples collected from the stream that flows around Plot M showed the same tritiated water concentration pattern seen in the past. Concentrations were at the ambient level of less than $0.1 \mathrm{nCi} / \mathrm{L}$ upstream of the Plot, increased up to $49 \mathrm{nCi} / \mathrm{L}$ at the seep adjacent to the Plot, then decreased to less than $0.1 \mathrm{nCi} / \mathrm{L}$ further downstream. These concentrations are lower than previous years. Other radiochemical analyses of water and stream-bed sediment collected above and below Plot $\mathrm{M}$ indicated that there are slightly elevated concentrations of strontium-90 in water and cesium-137 and plutonium-239 in sediment downstream from Plot M. For both the water and sediment samples, the upstream concentrations were comparable to ambient or fallout levels.

The tritiated water concentrations in the borehole and dolomite hole water follow a pattern consistent with that observed in the past. The tritium concentration was highest in 
those boreholes nearest Plot $M$ and downgradient of the Plot. Water from seven of 15 boreholes analyzed for strontium- 90 contained concentrations greater than the detection limit of $0.25 \mathrm{pCi} / \mathrm{L}$. The elevated strontium-90 levels (up to $5.70 \mathrm{pCi} / \mathrm{L}$ ) found in some boreholes are probably from the Plot, since concentrations above $0.25 \mathrm{pCi} / \mathrm{L}$ have not been observed in the groundwater due to atmospheric fallout from previous nuclear weapons testing, and no other source is known. Strontium-90 is a relatively mobile radionuclide and its presence in the borehole water is not unexpected and is probably due to migration that occurred before the Plot was capped. The strontium-90 results are consistent with those measured in the past.

Sampling of the forest preserve picnic wells shown in Figure 1.2 continued. In July 1988, the Red Gate Woods North (\#5160) well was installed as a replacement drinking water supply for the Red Gate Woods (\#5167) well. The maximum and average concentrations for the last few years for the Red Gate Woods North well (\#5160) and the Red Gate Woods well (\#5167) are presented in Table 2.1 and illustrated in Figure 2.1. The maximum concentration and the annual average of less than $0.1 \mathrm{nCi} / \mathrm{L}$ in the Red Gate Woods well (\#5167) are significantly less than in earlier years. The maximum and average concentrations of the well opposite Red Gate Woods (\#5159) were $2.26 \mathrm{nCi} / \mathrm{L}$ and $0.51 \mathrm{nCi} / \mathrm{L}$, respectively. The other wells were all less than $0.1 \mathrm{nCi} / \mathrm{L}$. The previous pattern of high tritium concentrations in the winter and low concentrations (less than the detection limit of $0.1 \mathrm{nCi} / \mathrm{L}$ ) in the summer is not readily apparent for the Red Gate Woods well (\#5167) because of the low tritium concentrations. In the calculation of annual averages, all data as measured were retained in the data base and used to compute the average.

If water equal to the Red Gate Woods North well (\#5160) average concentration of 0.51 $\mathrm{nCi} / \mathrm{L}$ were the sole source of water for an individual, the annual dose from tritium would be 0.023 mrem using the DOE dose conversion factor. Although not applicable, compared to the U. S. Environmental Protection Agency (EPA) drinking water limit, ${ }^{17}$ this concentration is about $2 \%$ of the annual limit of $20 \mathrm{nCi} / \mathrm{L}$. Consumption of one liter of this water 
TABLE 2.1

Annual Maximum and Average Hydrogen-3 Concentrations in the Red Gate Woods Wells

(Concentrations in $\mathrm{nCi} / \mathrm{L}$ )'

\begin{tabular}{lcccc}
\hline & \multicolumn{2}{c}{5167 (Original Well) } & \multicolumn{2}{c}{5160 (Replacement Well) } \\
Mearimum & Annual Average & Maximum & Annual Average \\
\hline & 3.0 & 2.2 & & \\
1983 & 2.7 & 1.2 & & \\
1984 & 2.5 & 1.0 & & \\
1985 & 3.4 & 1.3 & & \\
1986 & 3.3 & 1.6 & 0.19 & \\
1988 & 0.48 & 0.18 & 0.30 & 0.27 \\
1989 & 0.46 & 0.30 & 0.41 & 0.35 \\
1990 & 0.25 & 0.12 & 0.52 & 0.25 \\
1991 & 0.21 & $<0.1$ & 0.80 & 0.23 \\
1992 & 0.13 & $<0.1$ & 0.54 & 0.31 \\
1993 & $<0.1$ & $<0.1$ & 0.57 & 0.51 \\
1994 & $<0.1$ & $<0.1$ & 0.40 & \\
1995 & $<0.1$ & $<0.1$ & 2.26 & \\
\hline
\end{tabular}

*The replacement well (\#5160) was installed in July 1988.

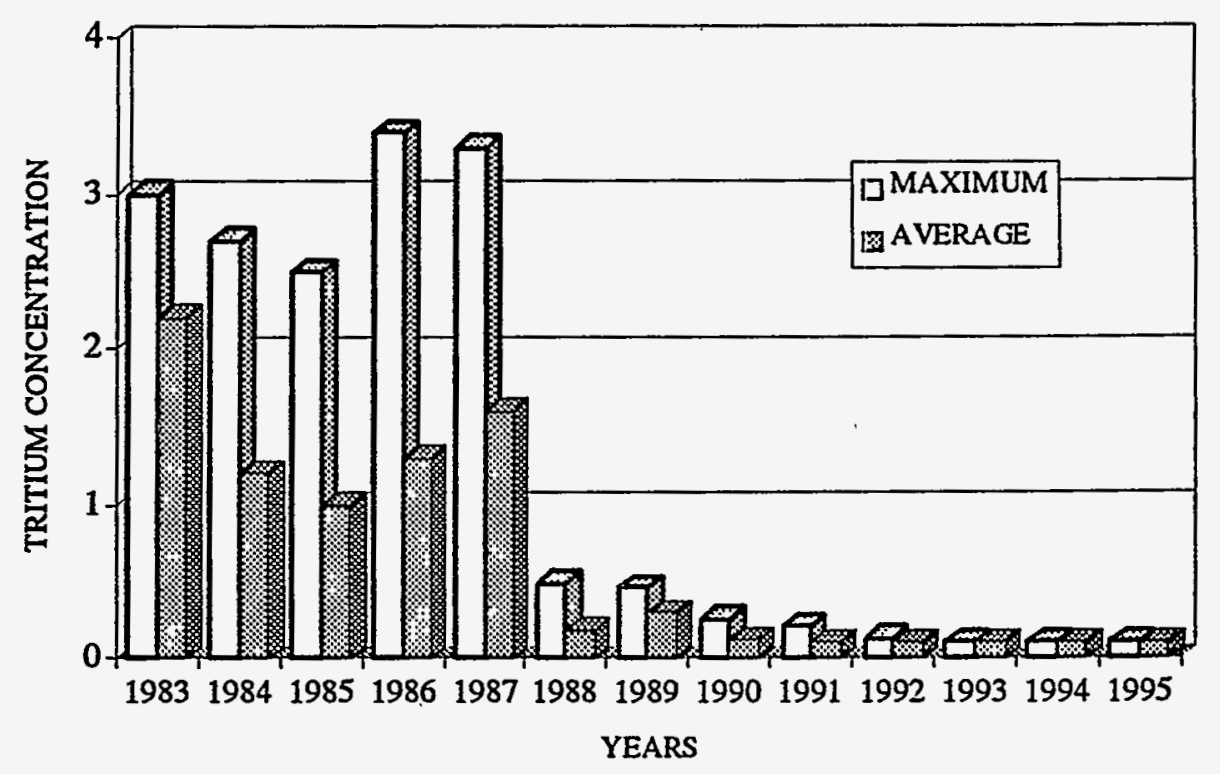

Figure 2.1 Trends in Tritium Concentrations in Red Gate Woods Well (\#5167)

(Concentrations in $\mathrm{nCi} / \mathrm{L}$ ) 
would produce a dose of $3 \times 10^{-5} \mathrm{mrem}$. Table 4.3 provides a relative comparison of this calculated dose to natural or accepted sources of radiation.

The results of this program show that the radioactivity remaining at Site A, Plot M, and the Red Gate Woods area does not endanger the health or safety of the public visiting the site or those living in the vicinity. The potential radiation doses are very low relative to the relevant standards.

\subsection{MONITORING PROGRAM}

The program is designed to monitor the elevated hydrogen-3 (as tritiated water) concentrations in some of the picnic wells in the Palos Forest Preserve, determine the migration pathway of water from the burial ground to the wells, establish if other buried radionuclides or waste constituents have migrated, and characterize the radiological and nonradiological pollutant environment of the area. This is accomplished by analyzing water vapor samples and water from wells, deep holes, boreholes, and surface streams in the area. Samples are collected from biweekly to annually, depending on past results and proximity to Plot M. During 1995, 393 samples were collected, 1,865 analyses were performed, and 201 field measurements conducted. For the most part, individual results are presented in the tables, and compared to control, off-site, or upstream results. Where applicable, results are compared to the U.S. Department of Energy Radiation Protection Standard of $100 \mathrm{mrem} / \mathrm{y}^{16}$ The Site A/Plot $M$ program follows the guidance for monitoring at DOE facilities. ${ }^{18}$ Although it is recognized that Site A/Plot M is not a DOE facility, the same monitoring principles are applicable to this site.

The uncertainties associated with individual concentrations given in the tables are the statistical counting errors at the $95 \%$ confidence level. A few tables of tritium data do not contain these uncertainties. In such cases, the following uncertainties apply: 
Concentration (nCi/L)

$0.1-1.0$

1-10

$>10$
Uncertainty (\% of Conc.)

40-5\%

$5-1 \%$

$1 \%$

The sensitivity for the measurement of tritium in water has been improved due to new instrumentation. The current detection limit is $0.1 \mathrm{nCi} / \mathrm{L}$. The detection limit for tritium in air is $0.1 \mathrm{pCi} / \mathrm{m}^{3}$.

\subsection{Air}

Since this stream drains tritiated water leached from the Plot, water vapor samples were collected over the surface of the stream next to Plot $M$ and analyzed for tritium to estimate the potential exposure from the atmospheric pathway. Samples were collected upstream and downstream of Plot $\mathrm{M}$ and the results are given in Table 3.1. The concentrations were higher below Plot $\mathrm{M}$ than above, where the levels were similar to ambient concentrations of tritium in air of $0.20 \mathrm{pCi} / \mathrm{m}^{3} .{ }^{19}$ The spring and fall averages are calculated using the actual measured values even though in many cases, the results are below the detection limit.

Although water was not flowing in the stream during some of the sampling periods, above-ambient tritiated water vapor concentrations were observed below the Plot. As was also observed last year, the downstream air concentrations were lower in the fall than the spring and are due to generally lower tritium stream concentrations in the fall and lower evapotranspiration. The dose to a hypothetical individual who breathed air continuously for one year at the maximum concentration of $46.7 \mathrm{pCi} / \mathrm{m}^{3}$ would be $0.025 \mathrm{mrem}$ or $0.02 \%$ of the applicable DOE environmental dose limit of $100 \mathrm{mrem} / \mathrm{y}$. This dose was calculated using the methodology specified in the DOE Order ${ }^{16}$ for determining radiation exposures to members of the public in uncontrolled areas. The total quantity of a radionuclide inhaled, in microcuries $(\mu \mathrm{Ci})$, is obtained by multiplying the air concentration by the general public 
TABLE 3.1

Concentrations of Tritiated Water Vapor Above the

Streambed Adjacent to Plot M, 1995

(Concentrations in $\mathrm{pCi} / \mathrm{m}^{3}$ )

\begin{tabular}{|c|c|c|}
\hline Sampling Period & $\begin{array}{l}\text { Location \#1* } \\
\text { (Upstream) }\end{array}$ & $\begin{array}{l}\text { Location \#9* } \\
\text { (Downstream) }\end{array}$ \\
\hline April 3 to April 6 & $<0.1$ & $10.0 \pm 0.3$ \\
\hline April 10 to April 13 & $0.2 \pm 0.3$ & $12.2 \pm 0.6$ \\
\hline April 17 to April 20 & $<0.1$ & $6.6 \pm 0.5$ \\
\hline April 24 to April 27 & $0.4 \pm 0.4$ & $46.7 \pm 1.1$ \\
\hline May 1 to May 4 & $0.4 \pm 0.3$ & $12.1 \pm 0.5$ \\
\hline Spring Average & $0.2 \pm 0.3$ & $17.5 \pm 14.7$ \\
\hline October 2 to October 5 & $1.8 \pm 0.6$ & $<0.1$ \\
\hline October 9 to October 12 & $1.0 \pm 0.5$ & $1.9 \pm 0.5$ \\
\hline October 16 to October 19 & $<0.1$ & $0.7 \pm 0.4$ \\
\hline October 24 to October 27 & $<0.1$ & $<0.1$ \\
\hline October 30 to November 2 & $<0.1$ & $<0.1$ \\
\hline Fall Average & $0.5 \pm 0.8$ & $0.4 \pm 0.8$ \\
\hline
\end{tabular}

*See Figure 3.1 
breathing rate of $8400 \mathrm{~m}^{3} / \mathrm{y}^{20}$ This annual intake is then multiplied by the 50-year Committed Effective Dose Equivalent (CEDE) factor to obtain the dose. ${ }^{21}$ The CEDE factor for tritiated water vapor is $6.3 \times 10^{-5} \mathrm{rem} / \mu \mathrm{Ci}$ (rem per microcurie).

\subsection{Surface Water}

Four sets of samples were collected from the stream that flows around Plot M. The stream was dry during scheduled sampling in July and September. The sampling locations are shown in Figure 3.1. The samples were analyzed for tritiated water and the results are in Table 3.2. The same concentration pattern in the water flowing around Plot $M$ was observed this year as in the past. Concentrations were low upstream of the Plot, increased as the stream flowed past the Plot, where it received tritiated water that leached out of the burial site, then decreased downstream due to dilution by precipitation. The outfall sample was collected prior to discharge into the I\&M Canal.

Using the methodology prescribed in the DOE guidance, ${ }^{16}$ the committed effective dose equivalent from consumption of water can be calculated. The total quantity of an ingested radionuclide is obtained by multiplying the water concentration by the general public water ingestion rate of $730 \mathrm{~L} / \mathrm{y} .{ }^{20}$ This annual intake is then multiplied by the 50 -year Committed Effective Dose Equivalent (CEDE) factor. ${ }^{21}$ The CEDE for tritium in water is $6.3 \times 10^{5}$ $\mathrm{rem} / \mu \mathrm{Ci}$. If a hypothetical individual used water with the same tritium concentration as found in the seep (Location \#6) as his sole source of water, the annual dose based on the maximum 1995 concentration of $48.7 \mathrm{nCi} / \mathrm{L}$ would be about $2.2 \mathrm{mrem} / \mathrm{y}$ and the dose based on the annual average seep concentration of $45.2 \mathrm{nCi} / \mathrm{L}$ would be $2.1 \mathrm{mrem} / \mathrm{y}$. The $\mathrm{DOE}$ dose limit to the public is $100 \mathrm{mrem} / \mathrm{y}$. Using the same calculations for concentrations at Location \#9, the maximum concentration of $13.5 \mathrm{nCi} / \mathrm{L}$ would produce $0.6 \mathrm{mrem} / \mathrm{y}$ and the 1995 average concentration of $10.6 \mathrm{nCi} / \mathrm{L}$ would give a dose of $0.5 \mathrm{mrem} / \mathrm{y}$. Conşumption of one liter of water with the same annual average concentration as at Location \#9 would produce a dose of $0.0007 \mathrm{mrem} / \mathrm{y}$. In general, the tritium concentrations are significantly 


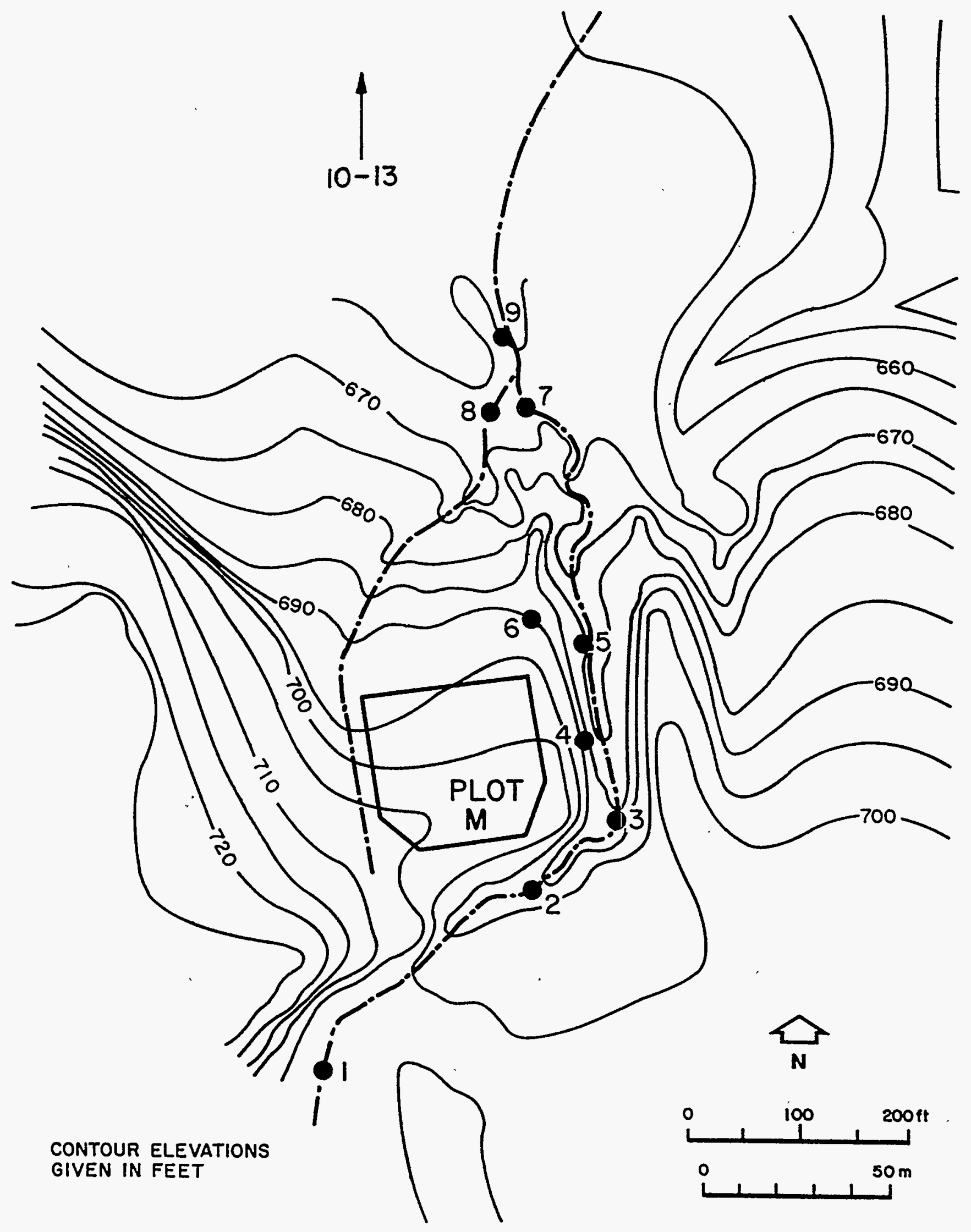

Figure 3.1 Surface Water Sampling Locations Near Plot M 
TABLE 3.2

Tritiated Water Content of Stream Next to Plot M, 1995

(Concentrations in $\mathrm{nCi} / \mathrm{L}$ )

\begin{tabular}{ccccc}
\hline \multirow{2}{*}{$\begin{array}{c}\text { Location } \\
\text { Number* }\end{array}$} & January 13 & March 13 & May 10 & November 10 \\
\cline { 2 - 5 } & $<0.1$ & $<0.1$ & $<0.1$ & $<0.1$ \\
1 & $<0.1$ & $<0.1$ & $<0.1$ & $<0.1$ \\
2 & $<0.1$ & $<0.1$ & $<0.1$ & $<0.1$ \\
3 & $0.4 \pm 0.1$ & $2.8 \pm 0.1$ & $9.7 \pm 0.1$ & $0.3 \pm 0.1$ \\
4 & $9.6 \pm 0.1$ & $10.9 \pm 0.1$ & $12.4 \pm 0.1$ & $4.6 \pm 0.1$ \\
5 & $41.4 \pm 0.2$ & $45.4 \pm 0.2$ & $48.7 \pm 0.2$ & - \\
6 (Seep) & $20.6 \pm 0.1$ & $13.8 \pm 0.1$ & $14.5 \pm 0.1$ & $4.9 \pm 0.1$ \\
7 & $2.6 \pm 0.1$ & $8.1 \pm 0.1$ & $7.8 \pm 0.1$ & $1.2 \pm 0.1$ \\
8 & $12.2 \pm 0.1$ & $12.7 \pm 0.1$ & $13.5 \pm 0.1$ & $4.2 \pm 0.1$ \\
9 & $14.0 \pm 0.1$ & $12.2 \pm 0.1$ & $12.6 \pm 0.1$ & $0.7 \pm 0.1$ \\
10 & $15.9 \pm 0.1$ & $10.3 \pm 0.1$ & $9.6 \pm 0.1$ & $0.5 \pm 0.1$ \\
11 & $<0.1$ & $4.3 \pm 0.1$ & $3.4 \pm 0.1$ & $<0.1$ \\
\hline Outfall** & & &
\end{tabular}

*See Figure 3.1

**I\&M Canal 
lower than past years and may be due to dilution from higher rates of precipitation during the sampling periods.

Large volume (20 liter) water samples were collected on May 10, 1995, and November 10, 1995, from this stream above Plot $M$ at Location \#1 and from below Plot $M$ at Location \#9. These samples were analyzed for the very low concentrations of other radionuclides that may be present to determine if any detectable amounts had migrated out of Plot $M$ and entered this surface stream. The results are given in Table 3.3. In addition to hydrogen-3, there are slightly elevated concentrations of strontium-90 at the downstream location. Strontium-90 has been found in the past in Borehole \#6 (see Figure 3.2), between Plot M and the stream, and its presence in the stream would be another indicator of possible migration of this radionuclide.

The annual collection of water samples from five surface water bodies in the vicinity of Site A occurred on December 6, 1995. These are: the pond northwest of Site A; the pond southeast of Site A; Horse Collar Slough; Tomahawk Slough; and Bull Frog Lake. Most of these locations can be identified in Figure 1.2. These samples were all analyzed for tritiated water and the concentrations were all less than the detection limit of $0.1 \mathrm{nCi} / \mathrm{L}$. The results indicate that there has been no surface migration of radioactive materials from Site A.

\subsection{Subsurface Water}

\subsubsection{Borehole Water - Plot M}

A number of the boreholes drilled in the Plot $M$ area (Figure 3.2) were cased with plastic pipe and screens were installed (piezometer) to serve as sampling points within the glacial till. Water samples were collected and water level measurements were made in the Plot $\mathrm{M}$ boreholes approximately bimonthly, weather permitting. Each borehole was emptied of water and allowed to recharge before sampling. The shallow boreholes responded to the 
TABLE 3.3

Radioactivity Content of Stream Next to Plot M, 1995

(Concentrations in $\mathrm{pCi} / \mathrm{L}$ )

\begin{tabular}{|c|c|c|c|}
\hline Constituent & Date & $\begin{array}{l}\text { Location \#1* } \\
\text { (Upstream) }\end{array}$ & $\begin{array}{l}\text { Location \#9* } \\
\text { (Downstream) }\end{array}$ \\
\hline Total Alpha** & $\begin{array}{l}\text { May } 10 \\
\text { November } 10\end{array}$ & $\begin{array}{l}0.73 \pm 0.14 \\
0.33 \pm 0.07\end{array}$ & $\begin{array}{l}0.34 \pm 0.13 \\
0.90 \pm 0.13\end{array}$ \\
\hline Total Beta** & $\begin{array}{l}\text { May } 10 \\
\text { November } 10\end{array}$ & $\begin{array}{l}5.36 \pm 0.20 \\
4.15 \pm 0.16\end{array}$ & $\begin{array}{l}5.14 \pm 0.21 \\
7.18 \pm 0.21\end{array}$ \\
\hline Hydrogen-3 & $\begin{array}{l}\text { May } 10 \\
\text { November } 10\end{array}$ & $\begin{array}{l}<100 \\
<100\end{array}$ & $\begin{aligned} 13200 & \pm 150 \\
4230 & \pm 91\end{aligned}$ \\
\hline Strontium-90 & $\begin{array}{l}\text { May } 10 \\
\text { November } 10\end{array}$ & $\begin{array}{l}0.57 \pm 0.03 \\
0.30 \pm 0.03\end{array}$ & $\begin{array}{l}0.92 \pm 0.03 \\
0.49 \pm 0.03\end{array}$ \\
\hline Uranium-234 & $\begin{array}{l}\text { May } 10 \\
\text { November } 10\end{array}$ & $\begin{array}{l}0.15 \pm 0.02 \\
0.04 \pm 0.01\end{array}$ & $\begin{array}{l}0.33 \pm 0.03 \\
0.13 \pm 0.03\end{array}$ \\
\hline Uranium-238 & $\begin{array}{l}\text { May } 10 \\
\text { November } 10\end{array}$ & $\begin{array}{l}0.13 \pm 0.02 \\
0.02 \pm 0.01\end{array}$ & $\begin{array}{l}0.34 \pm 0.03 \\
0.09 \pm 0.02\end{array}$ \\
\hline Neptunium-237 & $\begin{array}{l}\text { May } 10 \\
\text { November } 10\end{array}$ & $\begin{array}{l}<0.001 \\
<0.001\end{array}$ & $\begin{array}{l}<0.001 \\
<0.001\end{array}$ \\
\hline Plutonium-238 & $\begin{array}{l}\text { May } 10 \\
\text { November } 10\end{array}$ & $\begin{array}{l}<0.001 \\
<0.001\end{array}$ & $\begin{array}{l}<0.001 \\
<0.001\end{array}$ \\
\hline Plutonium-239 & $\begin{array}{l}\text { May } 10 \\
\text { November } 10\end{array}$ & $\begin{array}{l}<0.001 \\
<0.001\end{array}$ & $\begin{array}{l}<0.001 \\
<0.001\end{array}$ \\
\hline Americium-241 & $\begin{array}{l}\text { May } 10 \\
\text { November } 10\end{array}$ & $\begin{array}{l}<0.001 \\
<0.001\end{array}$ & $\begin{array}{l}<0.001 \\
<0.001\end{array}$ \\
\hline $\begin{array}{l}\text { Curium-242 and/or } \\
\text { Californium-252 }\end{array}$ & $\begin{array}{l}\text { May } 10 \\
\text { November } 10\end{array}$ & $\begin{array}{l}<0.001 \\
<0.001\end{array}$ & $\begin{array}{l}<0.001 \\
<0.001\end{array}$ \\
\hline $\begin{array}{l}\text { Curium-244 and/or } \\
\text { Californium-249 }\end{array}$ & $\begin{array}{l}\text { May } 10 \\
\text { November } 10\end{array}$ & $\begin{array}{l}<0.001 \\
<0.001\end{array}$ & $\begin{array}{l}<0.001 \\
<0.001\end{array}$ \\
\hline
\end{tabular}

\footnotetext{
* See Figure 3.1

** Non-volatile
} 


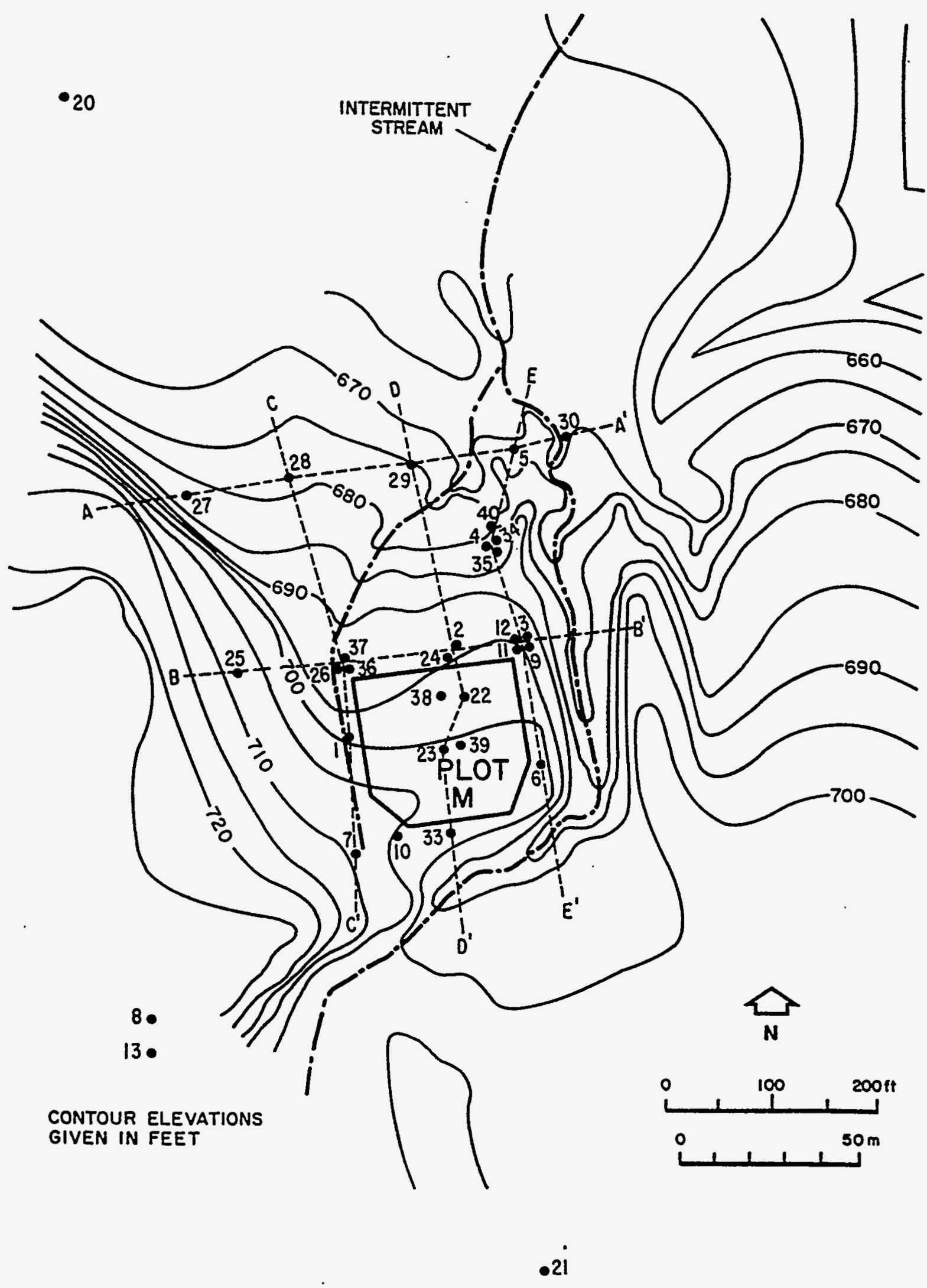

Figure 3.2 Map of Plot M Palos Site Showing Topography, Intermittent Stream, and Borehole Locations 
spring precipitation as indicated by an increase in water levels followed by a drop during summer and fall when moisture was used for plant growth. The water levels in the deeper boreholes ( $>100 \mathrm{ft}$ ) were relatively constant throughout the year. As in past years, some boreholes were occasionally dry. Borehole \#11 contains a nest of piezometers at three depths; 39 feet, 68 feet, and 124 feet. The principal purpose of this arrangement is to obtain water level measurements at different depths to determine the vertical gradient of the hydraulic head.

All the water samples were analyzed for tritiated water and the results are collected in Table 3.4. The tritium concentrations varied widely as in past years. In the 40-foot deep boreholes, low tritium concentrations correlate with high water levels, apparently a dilution phenomenon. The measured water levels in the boreholes are in Table 3.5. Since the measurement of the water levels is made relative to a benchmark at the top of the well casing, a decrease in numerical value indicates a rise in water level and dilution of the tritiated water. Higher tritiated water concentrations in borehole water correlate with higher tritium concentrations in split-spoon soil cores obtained when the boreholes were constructed. In general, the magnitude of the tritium concentrations are similar to those observed over the past several years. The elevated tritium concentrations in the October and November samples collected from Borehole \#8, are anomalies. There is no explanation for these results.

To visualize the data in Table 3.4, east-west elevation cross-sections of the subsurface tritium concentrations (Section B-B ${ }^{1}$ in Figure 3.2) were prepared for each of the sampling dates. These are collected in Figure 3.3 through Figure 3.8. The highest tritium concentrations appear to be located about 60 feet below the surface, slightly north of Plot M. This is consistent with past interpretations of tritiated water movement. Examination of the figures shows that the tritium concentrations increase from early in the year, peaking in the summer, and then decreasing the remainder of the year. This pattern is attributed to the loss 
TABLE 3.4

Tritium in Borehole Water, 1995

(Concentrations in $\mathrm{nCi} / \mathrm{L}$ )

\begin{tabular}{|c|c|c|c|c|c|c|c|}
\hline \multirow{2}{*}{$\begin{array}{l}\text { Borehole } \\
\text { Number }\end{array}$} & \multirow{2}{*}{$\begin{array}{l}\text { Depth } \\
\text { (ft) }\end{array}$} & \multicolumn{6}{|c|}{ Date Collected } \\
\hline & & February 3 & April 21 & June 14 & August 8 & October 26 & November 29 \\
\hline 1 & 39.46 & 1144.0 & 1256.0 & 1377.0 & 1553.0 & 1429.0 & 1340.0 \\
\hline 2 & 39.41 & 166.4 & 177.0 & 173.7 & 399.0 & 504.0 & 111.2 \\
\hline 3 & 40.00 & 2151.0 & 2078.0 & 2191.0 & 2280.0 & 2238.0 & 2333.0 \\
\hline 4 & 36.05 & 1360.0 & 1440.0 & 1561.0 & 1505.0 & 1321.0 & 1358.0 \\
\hline 5 & 40.20 & 59.1 & 64.9 & 69.7 & 63.7 & 61.7 & 71.7 \\
\hline 6 & 40.30 & 172.5 & 172.8 & 166.0 & 148.9 & 148.9 & 153.9 \\
\hline 8 & 40.00 & 0.3 & 0.2 & $<0.1$ & 0.1 & 7.1 & 13.1 \\
\hline 9 & $* 40.00$ & 6287.0 & 660.6 & 1388.0 & 12630 & 9945.0 & 10080.0 \\
\hline 10 & $* 40.00$ & 306.1 & 30.9 & 23.0 & 471.2 & 553.1 & Dry \\
\hline 11 & 39.30 & 447.3 & 529.2 & 427.3 & 640.4 & 728.1 & 672.3 \\
\hline 11 & 67.45 & 124.9 & Dry & Dry & Dry & Dry & Dry \\
\hline 11 & 121.90 & 9.4 & 4.6 & 13.9 & 28.0 & 8.1 & 5.4 \\
\hline 24 & 115.11 & 115.9 & 13.0 & 26.7 & 196.4 & 850.1 & 726.8 \\
\hline 26 & 60.65 & 325.4 & 236.4 & 432.2 & 574.2 & 580.5 & 569.7 \\
\hline 28 & 58.25 & 120.8 & 97.2 & 93.2 & 95.4 & 111.5 & Dry \\
\hline 35 & 105.50 & 240.2 & 274.7 & 594.0 & 432.9 & 239.5 & 398.1 \\
\hline 36 & 120.00 & 6.9 & 4.7 & 6.8 & 30.2 & 38.3 & 27.9 \\
\hline
\end{tabular}

*Slant hole drilled at $45^{\circ}$ to a depth of $40 \mathrm{ft}$ below the surface. 


\section{TABLE 3.5}

Water Level Measurements in Boreholes Near Plot M, 1995

(Units of feet below the benchmark at the top of the well)

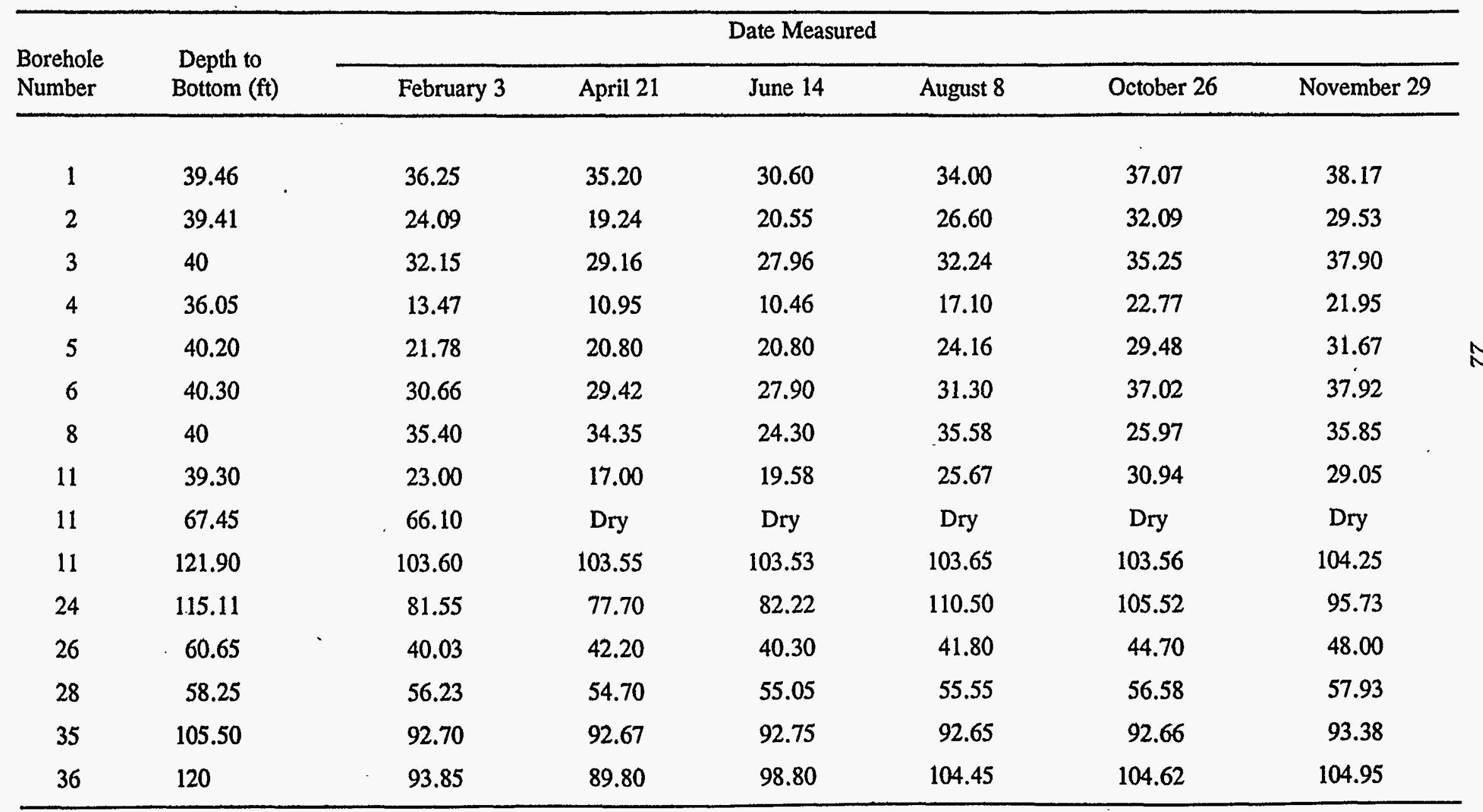



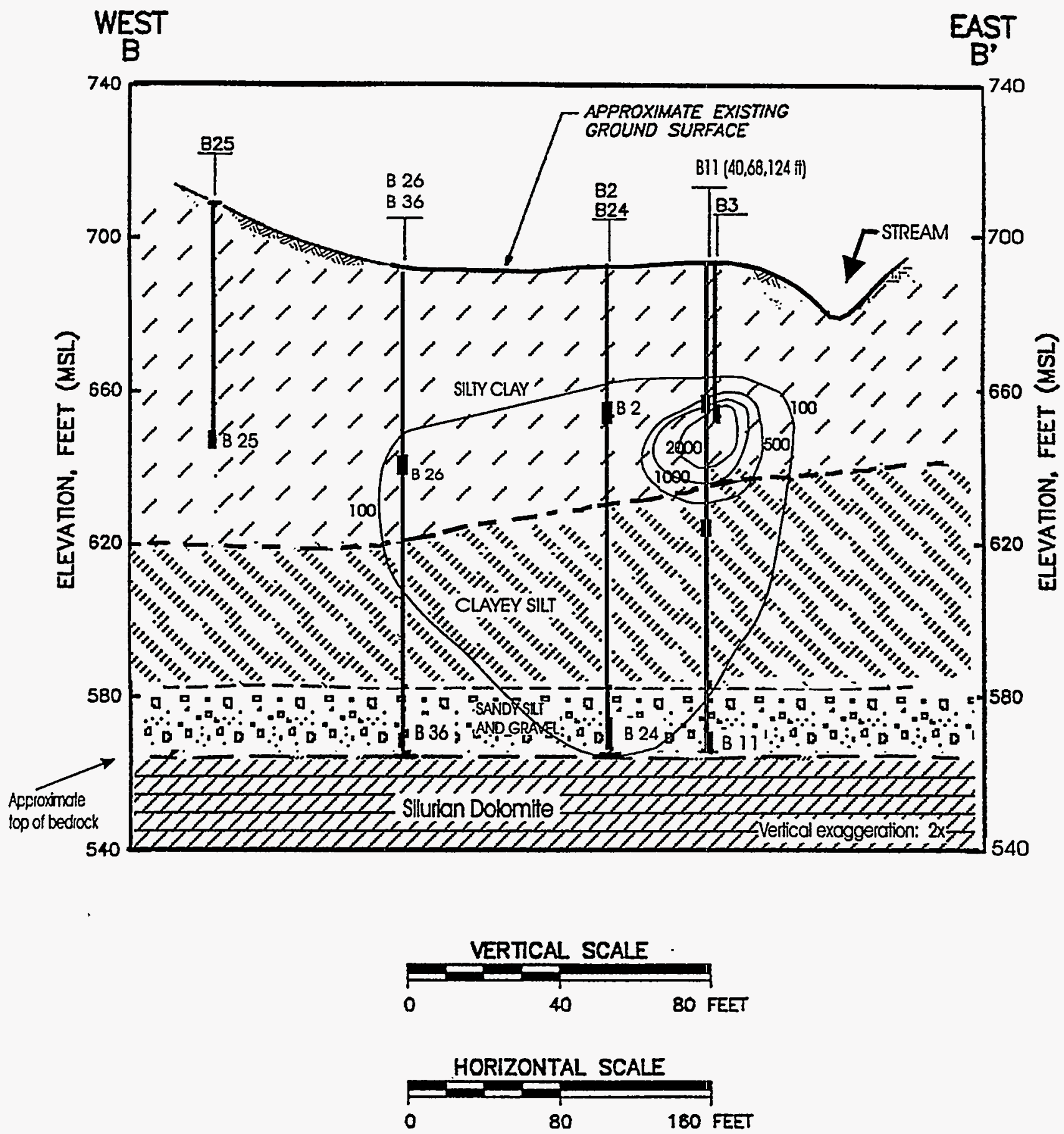

Figure 3.3 Subsurface Tritium Contours From the February 1995 Samples 

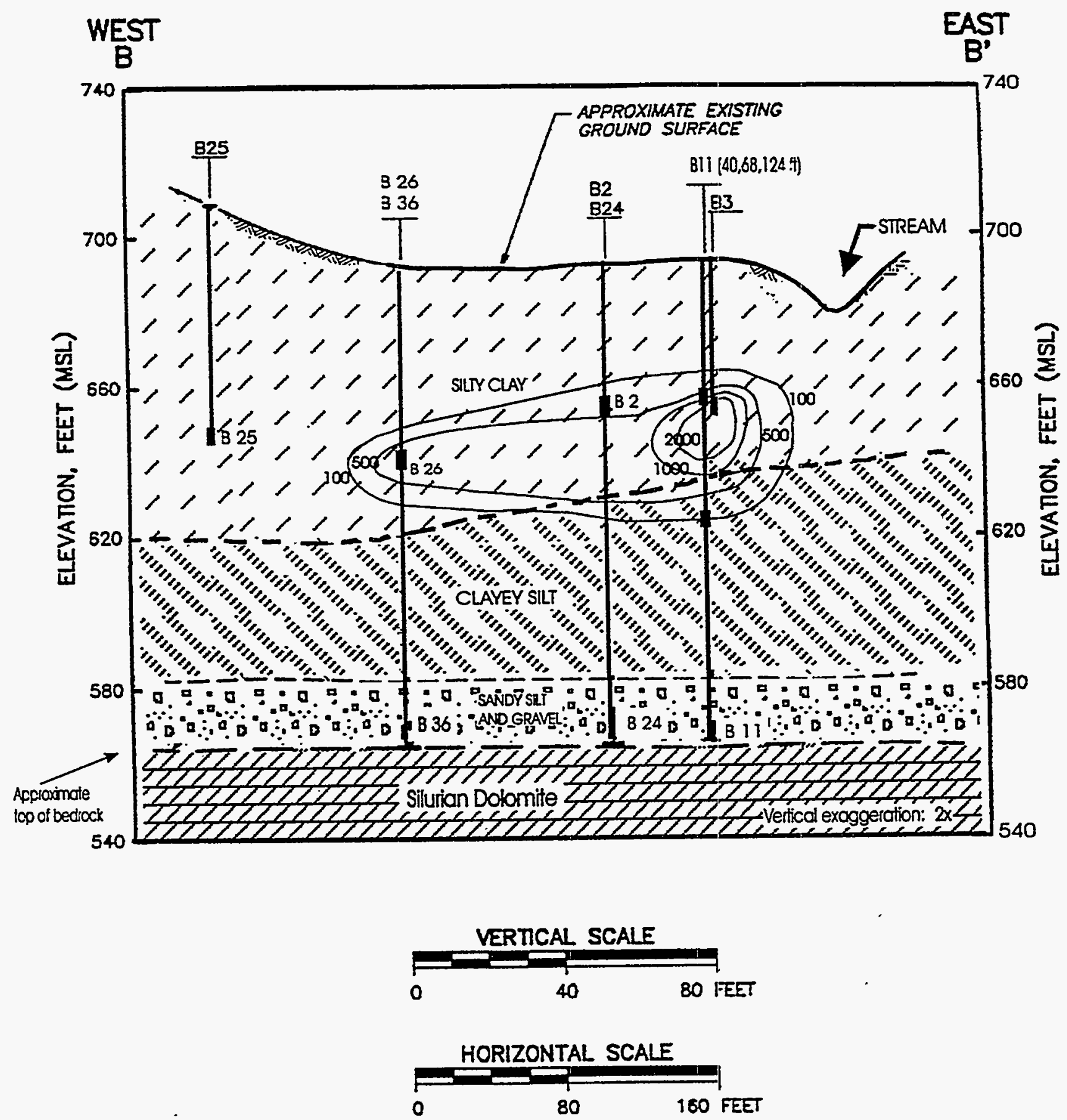

Figure 3.4 Subsurface Tritium Contours From the April 1995 Samples 


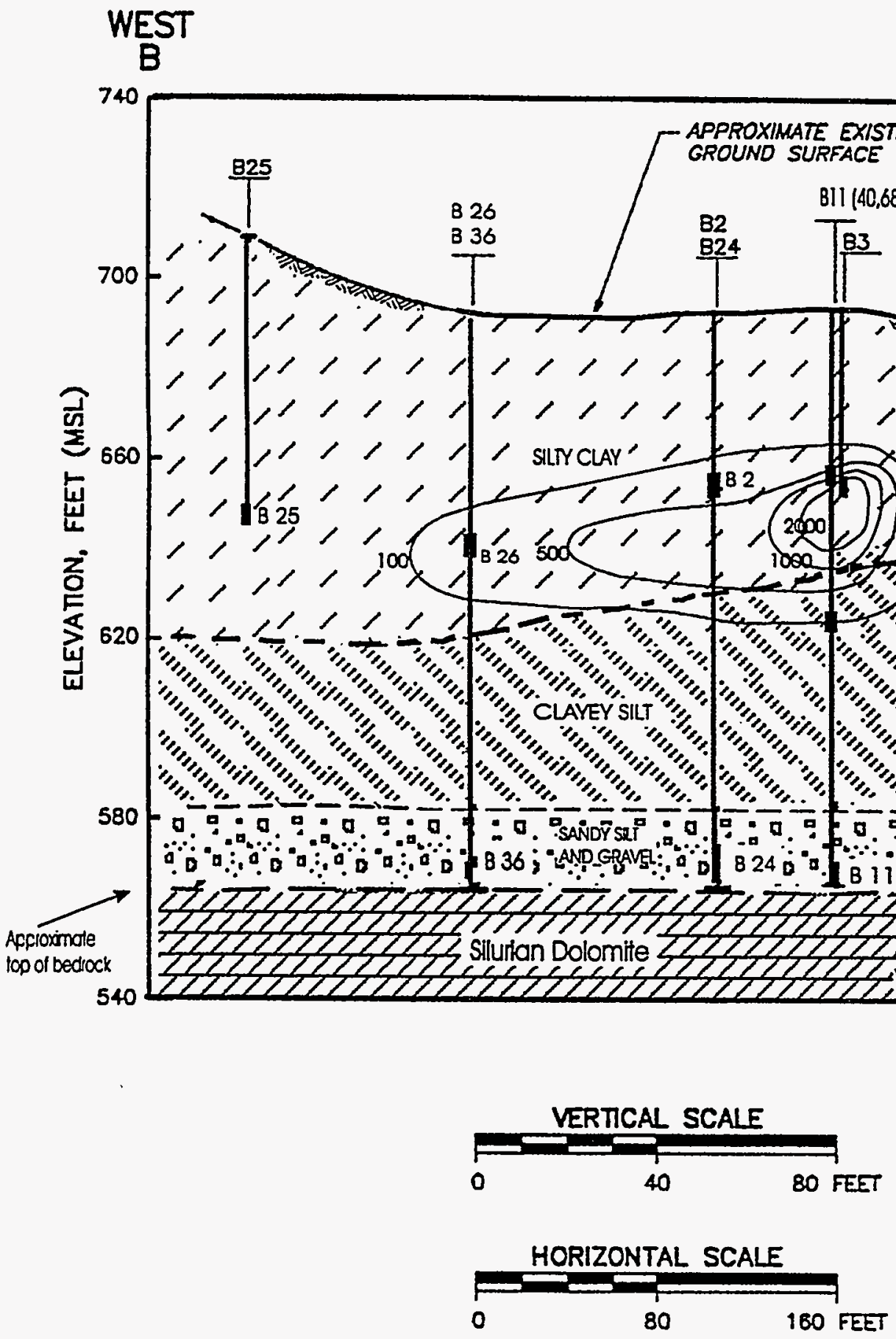

Figure 3.5 Subsurface Tritium Contours From the June 1995 Samples 

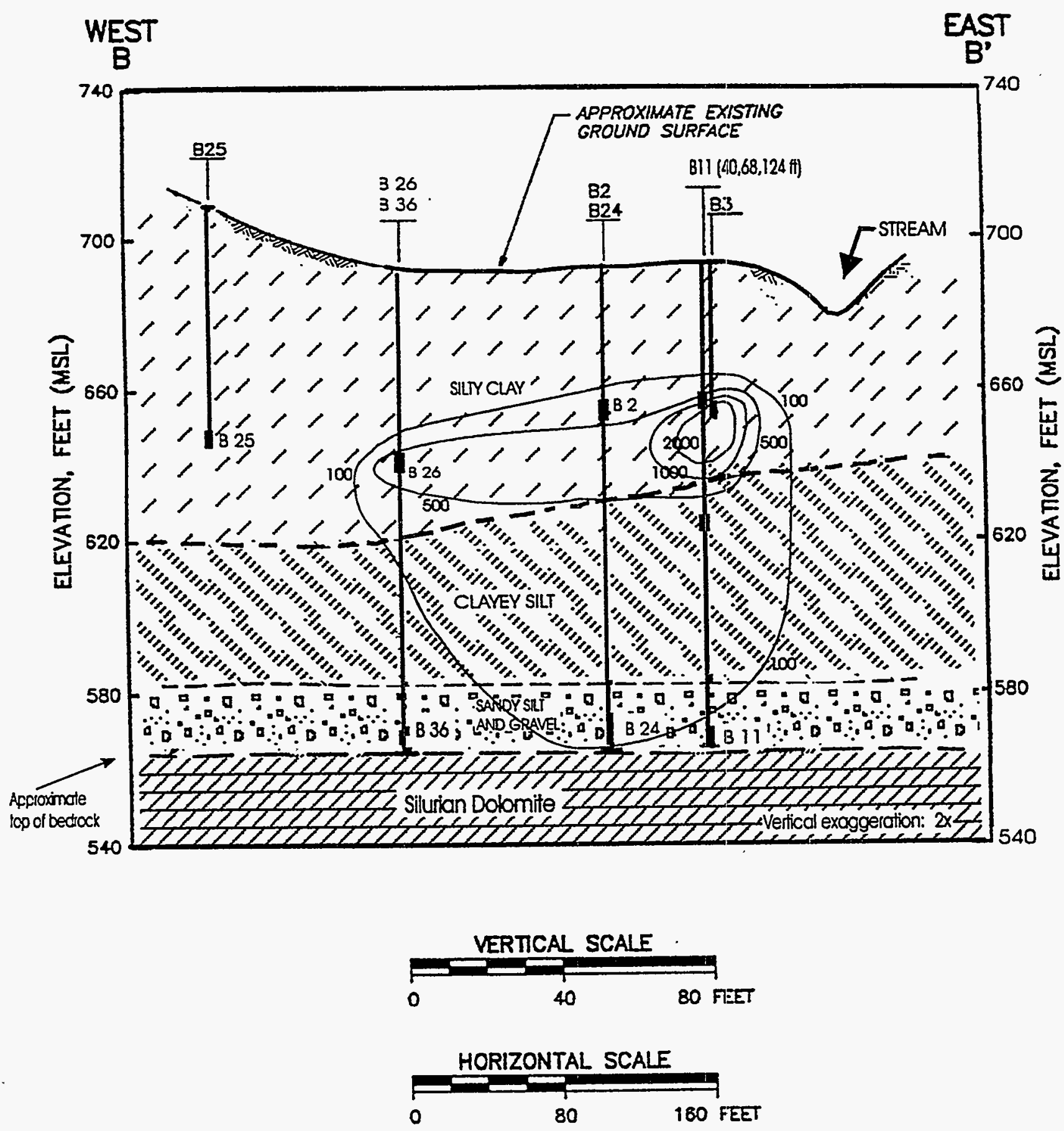

Figure 3.6 Subsurface Tritium Contours From the August 1995 Samples 


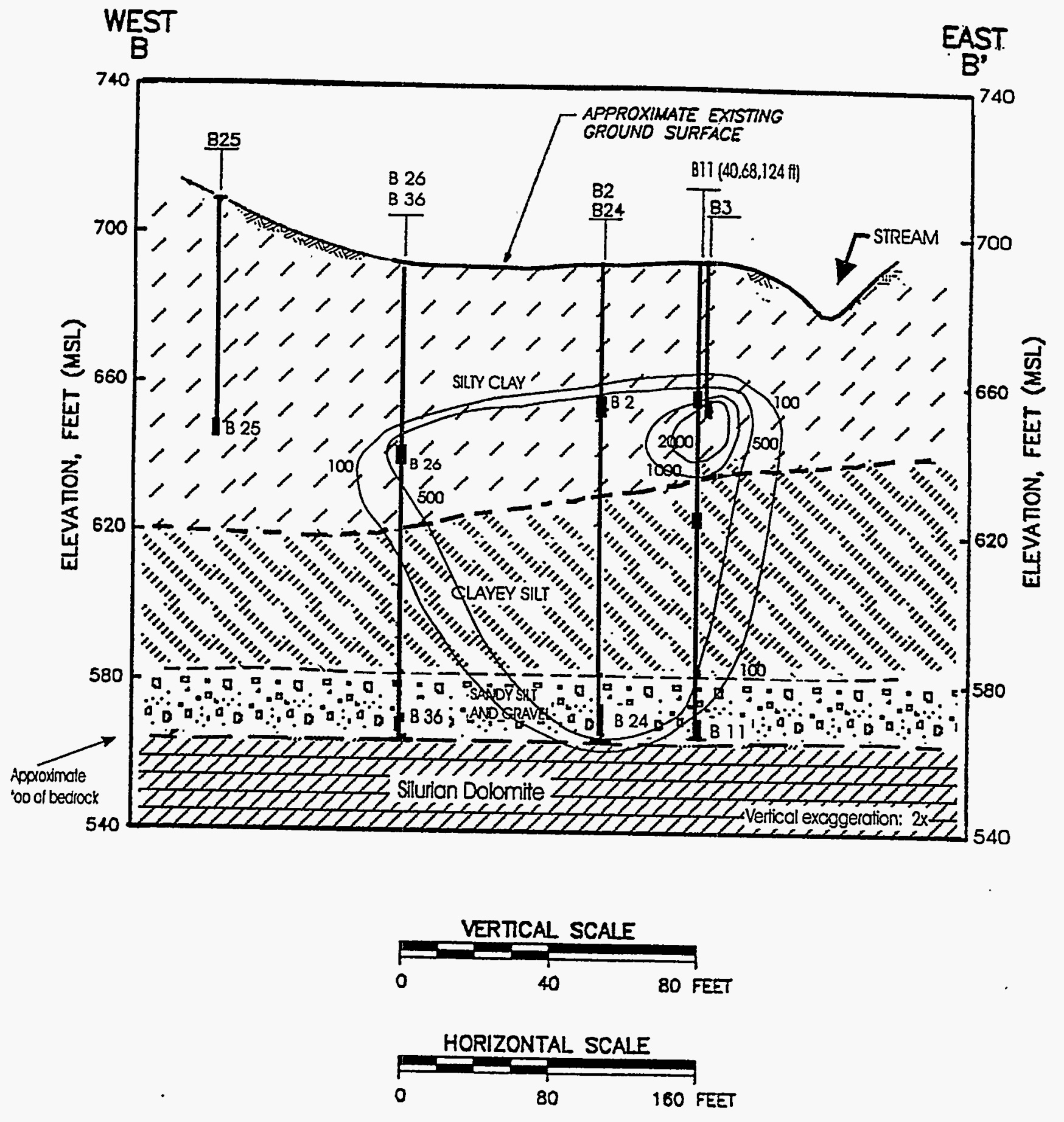

Figure 3.7 Subsurface Tritium Contours From the October 1995 Samples 

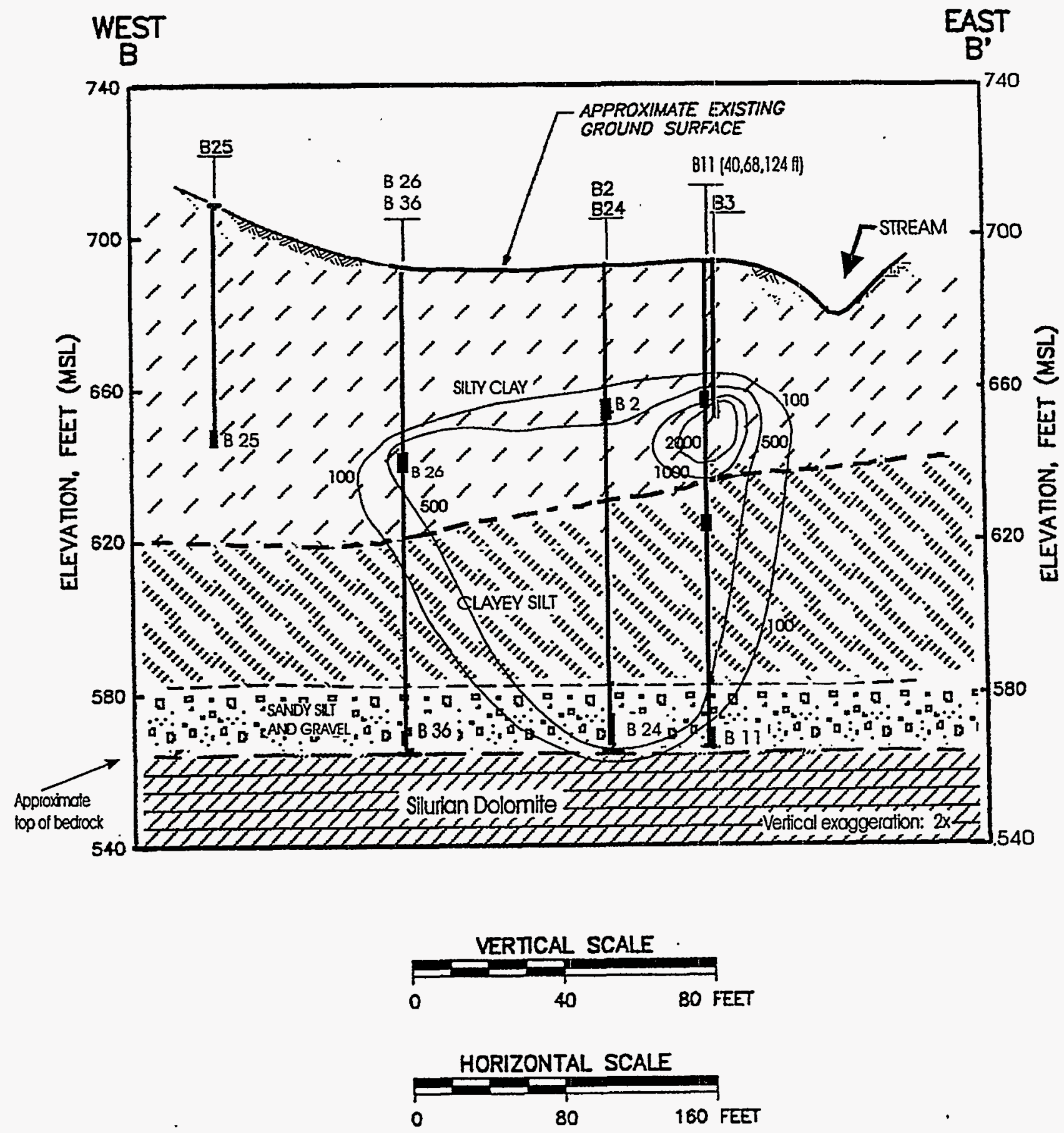

Figure 3.8 Subsurface Tritium Contours From the December 1995 Samples 
of precipitation recharge by plant use and evapotranspiration during the spring and summer and therefore not available for dilution of the tritiated water.

The EPA protocols suggest that a monitoring well be purged and a sample collected within the first two hours or the sample may not be representative of the groundwater. Geological conditions at Plot $M$ make it very difficult to follow the EPA guidance. Many of the monitoring wells at Plot $M$ have been placed in clay-rich units with very low permeability. Recharge to these monitoring wells over a two-hour period will be insufficient to obtain an appropriate volume (up to one gallon) of water to conduct the analytical tests. The EPA criteria applies to situations where sensitive constituents such as volatile organic chemicals are of concern. Groundwater analyses at Plot $M$ are for radioactive constituents, especially tritium which is less sensitive to chemical or physical loss from the groundwater than the volatile organic chemicals. However, the EPA sampling protocol was applied for all sampling during 1995, if appropriate.

As part of a search for radionuclides other than tritium in the borehole monitoring wells, sets of large volume water samples were collected to obtain greater sensitivity in the analysis. One set of samples was collected on April 21, 1995, and another set was collected November 29, 1995. Samples were collected from all boreholes that yielded sufficient water for analysis. All samples were analyzed for strontium-90 and the results are shown in Table 3.6. Strontium-90 concentrations greater than the detection limit of $0.25 \mathrm{pCi} / \mathrm{L}$ were found in seven of the 15 sampled boreholes. Levels above $0.25 \mathrm{pCi} / \mathrm{L}$ would not be expected in this water from fallout, and no other source is known. The highest strontium-90 concentrations were found in water from Borehole $\# 9(5.70 \mathrm{pCi} / \mathrm{L})$. The highest concentration found in 1991 was $10.7 \mathrm{pCi} / \mathrm{L}$ in Borehole \#11 (68'), $9.58 \mathrm{pCi} / \mathrm{L}$ in 1992 in Borehole \#11 (68'), 9.76 $\mathrm{pCi} / \mathrm{L}$ in Borehole \#11 (68') in 1993, and $3.42 \mathrm{nCi} / 1$ in Borehole $\# 9$ in 1994. It should be noted that in the past, the borehole with one of the higher strontium-90 concentrations (Borehole \#6) is between the buried waste and the stream that flows around Plot M. These data indicate small but measurable amounts of strontium- 90 have migrated from the waste into the 
TABLE 3.6

Radiochemical Analysis of Borehole Water Samples Near Plot M, 1995

(Concentrations in $\mathrm{pCi} / \mathrm{L}$ )

\begin{tabular}{|c|c|c|c|}
\hline $\begin{array}{l}\text { Borehole } \\
\text { Number* }\end{array}$ & $\begin{array}{l}\text { Depth } \\
\text { (ft) }\end{array}$ & $\begin{array}{l}\text { Date } \\
\text { Collected }\end{array}$ & Strontium-90 \\
\hline 1 & 39.46 & $\begin{array}{l}\text { April } 21 \\
\text { November } 29\end{array}$ & $\begin{array}{l}<0.25 \\
<0.25\end{array}$ \\
\hline 2 & 39.41 & $\begin{array}{l}\text { April } 21 \\
\text { November } 29\end{array}$ & $\begin{array}{l}<0.25 \\
<0.25\end{array}$ \\
\hline 3 & 40.00 & $\begin{array}{l}\text { April } 21 \\
\text { November } 29\end{array}$ & $\begin{array}{l}<0.25 \\
<0.25\end{array}$ \\
\hline 4 & 36.05 & $\begin{array}{l}\text { April } 21 \\
\text { November } 29\end{array}$ & $\begin{array}{l}<0.25 \\
<0.25\end{array}$ \\
\hline 5 & 40.20 & $\begin{array}{l}\text { April } 21 \\
\text { November } 29\end{array}$ & $\begin{array}{l}<0.25 \\
<0.25\end{array}$ \\
\hline 6 & 40.30 & $\begin{array}{l}\text { April } 21 \\
\text { November } 29\end{array}$ & $\begin{array}{l}0.29 \pm 0.10 \\
0.56 \pm 0.03\end{array}$ \\
\hline 8 & 40.00 & $\begin{array}{l}\text { April } 21 \\
\text { November } 29\end{array}$ & $\begin{array}{l}<0.25 \\
<0.25\end{array}$ \\
\hline 9 & 40.00 & $\begin{array}{l}\text { April } 21 \\
\text { November } 29\end{array}$ & $\begin{array}{l}4.66 \pm 0.06 \\
5.70 \pm 0.08\end{array}$ \\
\hline 10 & 40.00 & $\begin{array}{l}\text { April } 21 \\
\text { November } 29\end{array}$ & $0.28 \underset{I^{* *}}{ \pm} 0.02$ \\
\hline 11 & 39.30 & $\begin{array}{l}\text { April } 21 \\
\text { November } 29\end{array}$ & $\begin{array}{l}2.82 \pm 0.05 \\
2.96 \pm 0.05\end{array}$ \\
\hline 11 & 67.45 & $\begin{array}{l}\text { April } 21 \\
\text { November } 29\end{array}$ & $\begin{array}{l}I^{* *} \\
I^{* *}\end{array}$ \\
\hline 11 & 121.90 & $\begin{array}{l}\text { April } 21 \\
\text { November } 29\end{array}$ & $\begin{array}{c}0.52 \pm 0.03 \\
<0.25\end{array}$ \\
\hline 24 & 115.11 & $\begin{array}{l}\text { April } 21 \\
\text { November } 29\end{array}$ & $\begin{array}{l}<0.25 \\
<0.25\end{array}$ \\
\hline 26 & 60.65 & $\begin{array}{l}\text { April } 21 \\
\text { November } 29\end{array}$ & $\begin{array}{c}0.92 \pm 0.03 \\
<0.25\end{array}$ \\
\hline 28 & 58.25 & November 29 & $\mathrm{I}^{* *}$ \\
\hline 35 & 105.50 & $\begin{array}{l}\text { April } 21 \\
\text { November } 29\end{array}$ & $\begin{array}{l}0.43 \pm 0.02 \\
0.63 \pm 0.10\end{array}$ \\
\hline 36 & 120.00 & $\begin{array}{l}\text { April } 21 \\
\text { November } 29\end{array}$ & $\begin{array}{l}<0.25 \\
<0.25 \\
\end{array}$ \\
\hline
\end{tabular}

* See Figure 3.2

** Insufficient amount of water collected to run analysis. 
surrounding glacial till. As seen in Table 3.3, measurable strontium-90 concentrations were also found in the stream water below the Plot.

\subsubsection{Borehole Water - Site A}

In late 1993, four boreholes (BH-41, BH-42, BH-43, and BH-44), were installed at Site A (see Figure 3.9). Borehole \#43 has been dry since construction. During the first half of 1995, samples were collected every other month and analyzed for tritium and strontium-90. In the second half of the year, samples were collected quarterly and only analyzed for tritium.

Several years ago, 12 monitoring wells were constructed at Site A to support the expanded characterization of this area. With the characterization study completed in spring of 1995, the wells were transferred to the monitoring program for continued use as part of the surveillance network. These wells are also shown in Figure 3.9. Dedicated pumps and associated equipment were installed in July and quarterly samples collected during the second half of 1995. The samples were analyzed for tritium, strontium-90, isotopic uranium, gamma-ray emitters, and metals.

The tritium results for all the Site A boreholes are collected in Table 3.7. Water levels were also measured in these boreholes and these measurements are in Table 3.8. The tritium concentrations were all low, but the pattern throughout the year was erratic in some boreholes. For example, the tritium concentrations in Borehole \#41 ranged from $0.4 \mathrm{nCi} / \mathrm{L}$ to $5.1 \mathrm{nCI} / \mathrm{L}$, while in Borehole \#46, the tritium concentration went from $7.4 \mathrm{nCi} / \mathrm{L}$ to $<$ $0.1 \mathrm{nCi} / \mathrm{L}$ and in Borehole \#56 from $<0.1 \mathrm{nCi} / \mathrm{L}$ to $6.6 \mathrm{nCi} / \mathrm{L}$. Additional data will be needed to determine the concentrations and any pattern.

The results of the strontium-90 and isotopic uranium analyses are collected in Table 3.9. The elevated strontium-90 results appear to track with elevated tritium results. For example, 


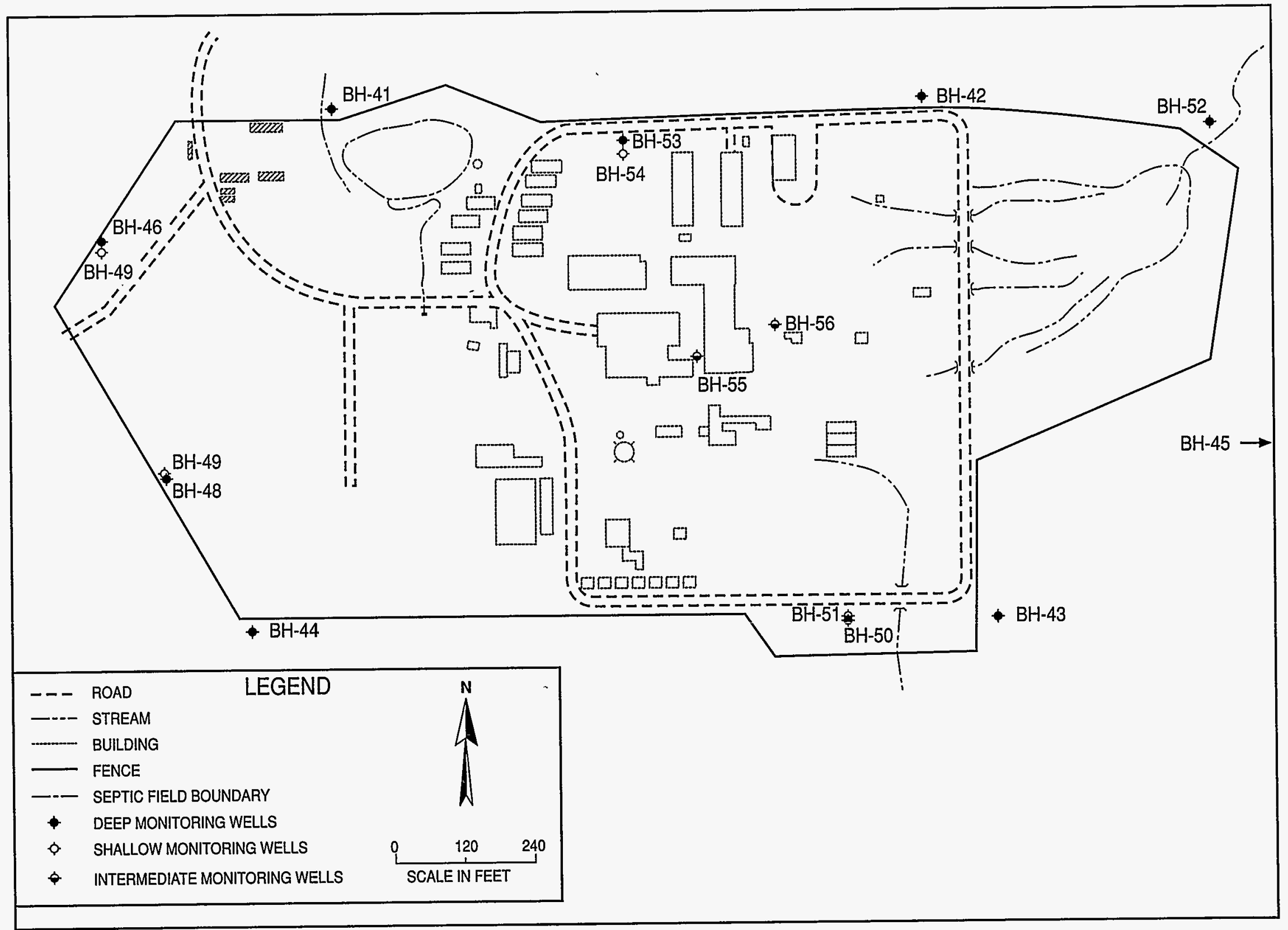

Figure 3.9 Monitoring Wells at Site A 
TABLE 3.7

Tritium in Site A Borehole Water, 1995

(Concentrations in $\mathrm{nCi} / \mathrm{L}$ )

\begin{tabular}{|c|c|c|c|c|c|c|c|}
\hline \multirow{2}{*}{$\begin{array}{l}\text { Borehole } \\
\text { Number }\end{array}$} & \multirow{2}{*}{$\begin{array}{c}\text { Bechtel } \\
\text { Well Number }\end{array}$} & \multirow{2}{*}{$\begin{array}{l}\text { Depth } \\
\text { (ft) }\end{array}$} & \multicolumn{5}{|c|}{ Date Collected } \\
\hline & & & March 24 & April 21 & June 16 & August 9 & November 20 \\
\hline 41 & - & 25 & 0.4 & 0.6 & 0.7 & 1.1 & 5.1 \\
\hline 42 & - & 52 & $<0.1$ & 1.5 & $<0.1$ & $<0.1$ & 1.4 \\
\hline 44 & - & 30 & 0.1 & $<0.1$ & $<0.1$ & 0.2 & 2.2 \\
\hline 45 & MW100 & 166 & - & - & - & $<0.1$ & $<0.1$ \\
\hline 46 & MW102 & 191 & - & - & - & 7.4 & $<0.1$ \\
\hline 47 & MW103 & 44 & - & - & - & $<0.1$ & 0.2 \\
\hline 48 & MW104 & 192 & - & - & - & $<0.1$ & $<0.1$ \\
\hline 49 & MW105 & 46 & - & - & - & $<0.1$ & $<0.1$ \\
\hline 50 & MW106 & 163 & - & - & - & 0.1 & $<0.1$ \\
\hline 51 & MW107 & 116 & - & - & - & $<0.1$ & $<0.1$ \\
\hline 52 & MW108 & 165 & - & - & - & $<0.1$ & 0.1 \\
\hline 53 & MW110 & 177 & - & - & - & $<0.1$ & $<0.1$ \\
\hline 54 & MW111 & 63 & - & - & - & 0.3 & Dry \\
\hline 55 & MW112 & 87 & - & - & - & 10.8 & Dry \\
\hline 56 & MW114 & 102 & - & - & - & $<0.1$ & 6.6 \\
\hline
\end{tabular}


TABLE 3.8

Water Level Measurements in Boreholes Near Site A, 1995

(Units in Feet Below the Benchmark at the Top of the Well)

\begin{tabular}{|c|c|c|c|c|c|c|}
\hline \multirow[b]{2}{*}{$\begin{array}{l}\text { Borehole } \\
\text { Number }\end{array}$} & \multirow{2}{*}{$\begin{array}{l}\text { Depth to } \\
\text { Bottom (ft) }\end{array}$} & \multicolumn{5}{|c|}{ Date Collected } \\
\hline & & March 24 & April 21 & June 16 & August 9 & November 20 \\
\hline 41 & 25.83 & 2.39 & 1.00 & 3.52 & 9.85 & 14.07 \\
\hline 42 & 53.01 & 49.53 & 48.85 & 49.78 & 47.13 & 48.85 \\
\hline 43 & 50 & Dry & Dry & Dry & Dry & Dry \\
\hline 44 & 31.02 & 4.32 & 2.40 & 4.72 & 10.80 & 16.20 \\
\hline 45 & 166.50 & - & - & - & 142.81 & 142.75 \\
\hline 46 & 190.80 & - & - & - & 156.45 & 156.92 \\
\hline 47 & 44.30 & - & - & - & 14.45 & 18.22 \\
\hline 48 & 192.20 & - & - & - & 158.82 & 159.30 \\
\hline 49 & 45.60 & - & - & - & 13.68 & 20.20 \\
\hline 50 & 162.80 & - & - & - & 104.22 & 105.12 \\
\hline 51 & 116.40 & - & - & - & 100.64 & 100.75 \\
\hline 52 & 165.00 & - & - & - & 131.70 & 131.94 \\
\hline 53 & 177.30 & - & - & - & 149.46 & 149.78 \\
\hline 54 & 63.40 & - & - & - & 51.44 & 55.57 \\
\hline 55 & 87.20 & - & - & - & 71.03 & 87.00 \\
\hline 56 & 102.40 & - & - & - & 86.45 & 86.23 \\
\hline
\end{tabular}


TABLE 3.9

Radiochemical Analysis of Borehole Water Samples Near Site A, 1995

(Concentrations in $\mathrm{pCi} / \mathrm{L}$ )

\begin{tabular}{|c|c|c|c|c|c|}
\hline $\begin{array}{l}\text { Borehole } \\
\text { Number* }\end{array}$ & $\begin{array}{l}\text { Depth } \\
\text { (ft) }\end{array}$ & $\begin{array}{l}\text { Date } \\
\text { Collected }\end{array}$ & Strontium-90 & Uranium-234 & Uranium-238 \\
\hline 41 & 25.83 & $\begin{array}{l}\text { March } 24 \\
\text { April 21 } \\
\text { June } 16\end{array}$ & $\begin{array}{l}0.54 \pm 0.03 \\
0.42 \pm 0.03 \\
0.33 \pm 0.03\end{array}$ & - & : \\
\hline 42 & 53.01 & $\begin{array}{l}\text { March } 24 \\
\text { April } 21 \\
\text { June } 16\end{array}$ & $\begin{array}{l}0.32 \pm 0.03 \\
0.48 \pm 0.03 \\
0.42 \pm 0.05\end{array}$ & - & - \\
\hline 43 & 50.00 & $\begin{array}{l}\text { March } 24 \\
\text { April } 21 \\
\text { June } 16\end{array}$ & $\begin{array}{l}\text { Dry } \\
\text { Dry } \\
\text { Dry }\end{array}$ & $\begin{array}{l}\text { Dry } \\
\text { Dry } \\
\text { Dry }\end{array}$ & $\begin{array}{l}\text { Dry } \\
\text { Dry } \\
\text { Dry }\end{array}$ \\
\hline 44 & 31.02 & $\begin{array}{l}\text { March } 24 \\
\text { April } 21 \\
\text { June } 16\end{array}$ & $\begin{array}{l}<0.25 \\
<0.25 \\
<0.25\end{array}$ & : & - \\
\hline 45 & 166.50 & $\begin{array}{l}\text { August } 9 \\
\text { November } 20\end{array}$ & $\begin{array}{l}<0.25 \\
<0.25\end{array}$ & $\begin{array}{l}0.13 \\
0.25\end{array}$ & $\begin{array}{l}0.09 \\
0.16\end{array}$ \\
\hline 46 & 190.80 & $\begin{array}{l}\text { August } 9 \\
\text { November } 20\end{array}$ & $\begin{array}{l}3.48 \pm 0.15 \\
<0.25\end{array}$ & $\begin{array}{l}0.95 \\
0.21\end{array}$ & $\begin{array}{l}0.70 \\
0.11\end{array}$ \\
\hline 47 & 44.30 & $\begin{array}{l}\text { August } 9 \\
\text { November } 20\end{array}$ & $\begin{array}{l}<0.25 \\
<0.25\end{array}$ & $\begin{array}{l}0.13 \\
3.98\end{array}$ & $\begin{array}{l}0.09 \\
4.29\end{array}$ \\
\hline 48 & 192.20 & $\begin{array}{l}\text { August } 9 \\
\text { November } 20\end{array}$ & $\begin{array}{l}<0.25 \\
<0.25\end{array}$ & $\begin{array}{l}0.09 \\
0.28\end{array}$ & $\begin{array}{l}0.05 \\
0.16\end{array}$ \\
\hline 49 & 45.60 & $\begin{array}{l}\text { August } 9 \\
\text { November } 20\end{array}$ & $\begin{array}{l}<0.25 \\
<0.25\end{array}$ & $\begin{array}{l}4.95 \\
8.98\end{array}$ & $\begin{array}{l}4.53 \\
8.20\end{array}$ \\
\hline 50 & 162.80 & $\begin{array}{l}\text { August } 9 \\
\text { November } 20\end{array}$ & $\begin{array}{l}<0.25 \\
<0.25\end{array}$ & $\begin{array}{l}0.58 \\
0.73\end{array}$ & $\begin{array}{l}0.48 \\
0.59\end{array}$ \\
\hline 51 & 116.40 & $\begin{array}{l}\text { August } 9 \\
\text { November } 20\end{array}$ & $\begin{array}{l}<0.25 \\
<0.25\end{array}$ & $\begin{array}{l}0.91 \\
1.36\end{array}$ & $\begin{array}{l}0.69 \\
1.01\end{array}$ \\
\hline 52 & 165.00 & $\begin{array}{l}\text { August } 9 \\
\text { November } 20\end{array}$ & $\begin{array}{l}<0.25 \\
<0.25\end{array}$ & $\begin{array}{l}0.32 \\
0.27\end{array}$ & $\begin{array}{l}0.24 \\
0.18\end{array}$ \\
\hline 53 & 177.30 & $\begin{array}{l}\text { August } 9 \\
\text { November } 20\end{array}$ & $\begin{array}{l}<0.25 \\
<0.25\end{array}$ & $\begin{array}{l}0.51 \\
0.70\end{array}$ & $\begin{array}{l}0.34 \\
0.38\end{array}$ \\
\hline 54 & 63.40 & $\begin{array}{l}\text { August } 9 \\
\text { November } 20\end{array}$ & $\begin{array}{c}<0.25 \\
\text { Dry }\end{array}$ & $\begin{array}{l}6.59 \\
\text { Dry }\end{array}$ & $\begin{array}{l}5.83 \\
\text { Dry }\end{array}$ \\
\hline 55 & 87.20 & $\begin{array}{l}\text { August } 9 \\
\text { November } 20\end{array}$ & $\begin{array}{c}10.11 \pm 0.20 \\
\text { Dry }\end{array}$ & $\begin{array}{l}7.04 \\
\text { Dry }\end{array}$ & $\begin{array}{l}6.48 \\
\text { Dry }\end{array}$ \\
\hline 56 & 102.40 & $\begin{array}{l}\text { August } 9 \\
\text { November } 20\end{array}$ & $\begin{array}{l}<0.25 \\
2.34 \pm 0.06\end{array}$ & $\begin{array}{l}4.22 \\
2.87\end{array}$ & $\begin{array}{l}3.47 \\
2.15\end{array}$ \\
\hline
\end{tabular}


Borehole \#46 had measurable levels of tritium and strontium-90 in the August 9, 1995 sample, but both tritium and strontium- 90 were below their respective detection limits in the November 20, 1995 sample. The situation also occurred in the samples from Borehole \#56. The isotopic uranium concentrations were elevated in a few boreholes. There is insufficient information to conclude if the source of the uranium was from operations at Site A. Another potential source of the uranium is the bentonite used to seal the wells. ${ }^{6}$ The boreholes were sealed with bentonite and bentonite was observed in some borehole water samples. The uranium concentration in the bentonite is about $10 \mathrm{pCi} / \mathrm{g}$. Since some of the water may have tens of grams of material suspended in the borehole water, the uranium in the borehole water may be from the bentonite packing material. Additional data will be required to determine the source of the uranium. All gamma-ray emitters were below the detection limit of 1 $\mathrm{pCi} / \mathrm{L}$.

The Site A borehole water samples were also analyzed for metals. These included: antimony; arsenic; beryllium, cadmium; chromium; copper; lead; mercury; nickel; selenium; silver, thallium; and zinc. The concentrations for the various metals were below their respective water quality standards ${ }^{23}$ except for the chromium levels in a few wells.

\subsubsection{Dolomite Hole Water}

At the present time, 15 wells are cased into the dolomite zone to monitor the movement of any radionuclides in this aquifer. Most of the dolomite holes are located north of Plot $\mathrm{M}$ and east of the Red Gate Woods wells (\#5160 and \#5167), as shown in Figure 1.2 and/or Figure 3.10. Water was collected from the dolomite holes quarterly. All samples were analyzed for tritiated water and the results are in Table 3.10. Water levels were also measured in the dolomite holes and these measurements are in Table 3.11. In December 1993, DH-13 was cleared of debris and DH-11 through DH-14 were grouted with cement to $535 \mathrm{ft}$ MSL. The purpose of the grouting was to seal off the lower dolomite fractures that are connected to the hand-pumped picnic wells in the Red Gate Woods area. It is speculated that these 


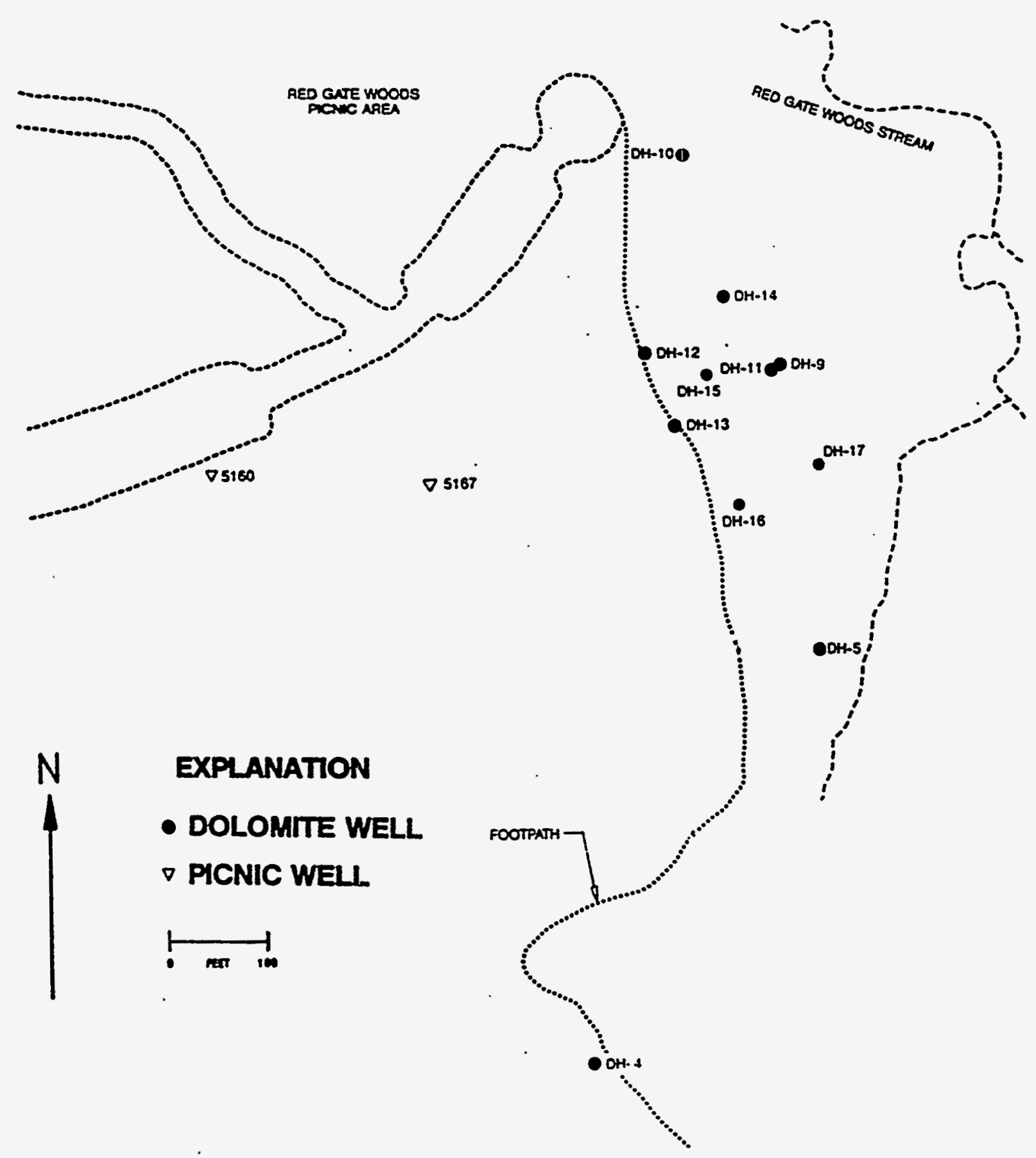

Figure 3.10 Locations of Dolomite Holes North of Plot M 
TABLE 3.10

Tritium in Site A Dolomite Holes, 1995

(Concentrations in $\mathrm{nCi} / \mathrm{L}$ )

\begin{tabular}{lrrrr}
\hline $\begin{array}{l}\text { Dolomite } \\
\text { Hole } \\
\text { Number }\end{array}$ & \multicolumn{4}{c}{ Date Collected } \\
\cline { 2 - 5 } & March 13 & June 23 & September 20 & December 6 \\
\hline & & & & \\
1 & $<0.1$ & $<0.1$ & $<0.1$ & $<0.1$ \\
2 & $<0.1$ & $<0.1$ & $<0.1$ & $<0.1$ \\
3 & 1.5 & 1.5 & 1.5 & 1.4 \\
4 & 0.3 & $<0.1$ & $<0.1$ & $<0.1$ \\
5 & $<0.1$ & $<0.1$ & $<0.1$ & $<0.1$ \\
9 & 2.8 & 2.8 & 2.0 & 1.7 \\
10 & 3.1 & 3.2 & 3.1 & 2.9 \\
11 & 4.0 & 3.4 & 5.2 & 5.4 \\
12 & 2.3 & 3.2 & 3.4 & 3.1 \\
13 & 2.1 & 2.6 & 2.3 & 2.4 \\
14 & 1.5 & 3.9 & 3.9 & 3.8 \\
15 & 1.9 & 0.4 & 2.3 & 3.8 \\
16 & $<0.1$ & $<0.1$ & $<0.1$ & $<0.1$ \\
17 & 0.3 & 0.6 & 0.6 & 0.4 \\
18 & $<0.1$ & $<0.1$ & $<0.1$ & $<0.1$ \\
\hline
\end{tabular}


TABLE 3.11

Water Level Measurements in Dolomite Holes, 1995

(Units of feet below the benchmark at the top of the well)

\begin{tabular}{rrrrr}
\hline $\begin{array}{l}\text { Dolomite } \\
\text { Hole } \\
\text { Number }\end{array}$ & \multicolumn{4}{c}{ Date Measured } \\
\cline { 2 - 5 } & March 13 & June 23 & September 20 & December 6 \\
\hline 1 & 161.25 & 160.55 & 162.10 & 162.15 \\
2 & 139.64 & 139.03 & 140.55 & 140.58 \\
3 & 98.14 & 97.56 & 99.06 & 99.06 \\
4 & 93.35 & 92.85 & 94.22 & 94.35 \\
5 & 78.06 & 77.65 & 79.08 & 79.06 \\
9 & 72.68 & 71.80 & 72.85 & 73.17 \\
10 & 63.90 & 63.40 & 64.85 & 64.84 \\
11 & 76.10 & 75.71 & 77.16 & 76.98 \\
12 & 77.09 & 76.71 & 78.03 & 75.04 \\
13 & 77.71 & 77.22 & 78.64 & 78.65 \\
14 & 72.08 & 71.60 & 73.01 & 73.02 \\
15 & 79.71 & 79.40 & 80.63 & 80.64 \\
16 & 75.85 & 75.36 & 76.83 & 76.83 \\
17 & 74.98 & 74.48 & 75.94 & 75.90 \\
18 & 143.56 & 141.95 & 144.09 & 144.11 \\
& & & & \\
\hline
\end{tabular}


lower fractures allow elevated levels of tritiated water in the dolomite holes to migrate to the picnic well. In addition, covers to three of the dolomite holes were repaired.

In September 1994, three of the dolomite holes, DH-6, DH-7, and DH-8, were abandoned because the wells were not sealed into the dolomite, but were open to the glacial till. As such, they were not sampling dolomite water. Borehole \#40 was also abandoned at the same time. The casing was filled with clean gravel and sand, sealed with bentonite, the casing removed to three feet below the ground level, and backfilled with clean soil.

The results of the tritiated water analyses of the dolomite holes are consistent with concentrations measured in the past. In all, nine of the dolomite holes had elevated tritiated water concentrations. The highest tritium levels are in the eight dolomite holes, $\mathrm{DH} 9$ to $\mathrm{DH}$ 15 and DH 17, which are the furthest north and near the surface stream that flows next to Plot M (see Section 3.2). The distribution of tritium in these wells supports the USGS interpretation $^{22}$ that a large tritium plume underlies the stream. The plume has spread downward as well as downgradient resulting in the current configuration of the tritium concentrations in the dolomite. The other dolomite hole with elevated tritium is DH 3 , which is immediately downgradient from Plot M. Previous analyses of soil core samples indicated the presence of tritium down to the till-dolomite interface at DH 3.

Beginning in December of 1992, a study was initiated to compare tritium concentrations in the dolomite holes with and without purging. Before that date, samples were collected by a bailer without purging. Each quarter in 1993, 1994, and 1995 wells were chosen on an alternating schedule for purging or not purging. Purging consisted of removing up to 700 liters of water before sample collection.

The tritium concentrations in those dolomite holes that were below the detection limit (DH $1,2,5,7,8$, and 16) displayed no significant difference after purging. Most of the other dolomite holes (DH 3,10-12, 14, 15, and 17) displayed differences in tritium 
concentrations that can be associated with the pumping. Samples collected after purging these wells have distinctly lowered concentrations than without purging. If the dolomite hole was not purged the next quarter, the tritium concentration returned to the previous level. In addition, samples collected in the upper part of the water column had higher tritium concentrations than those collected in the lower part of the water column. These differences are illustrated in Figure 3.11.

The current explanation for the differences in tritium concentration is that the tritium is moving horizontally in the uppermost fractures of the dolomite. The tritium is in a narrow band of the water column in the dolomite hole. Where a sample is collected with a bailer, this tritium zone is the area sampled resulting in measurable levels of tritium in the sample. However, when the dolomite hole is purged, the volume of recharge water from other fractures that are free of tritium is such that the tritium concentration in the sample is generally at the detection limit. If the next quarter sample is collected without purging, the tritium concentration is at the same level as earlier samples indicating that the fracture flow rapidly reached an equilibrium condition. Further studies need to be conducted to confirm this hypothesis.

A study was conducted to determine if any chemical constituents used or generated at Site $\mathrm{A}$ and/or buried at Plot $\mathrm{M}$ entered the environment and migrated into the dolomite water. Samples were collected each quarter from DH 1, DH 2, DH 3, and DH 4 (see Figure 1.2). These samples were analyzed for volatile organic compounds. Of the samples collected in the last quarter of 1991 and the first three quarters of 1992, acetone and methyl ethyl ketone were identified in DH 1. The fourth quarter sample in 1992 and all the 1993 and 1994 samples contained only acetone (up to $480 \mu \mathrm{g} / \mathrm{L}$ ) but acetone was also identified in the laboratory blanks. During 1995, acetone concentrations varied from $88 \mu \mathrm{g} / \mathrm{L}$ to 306 $\mu \mathrm{g} / \mathrm{L}$. Methyl ethyl ketone was also identified in DH 1 during 1995 and ranged in concentration from $7 \mu \mathrm{g} / \mathrm{L}$ to $24 \mu \mathrm{g} / \mathrm{L}$. Since the concentrations changed rapidly and no hydrogen-3 was ever observed in this dolomite water, it may imply analytical laboratory 


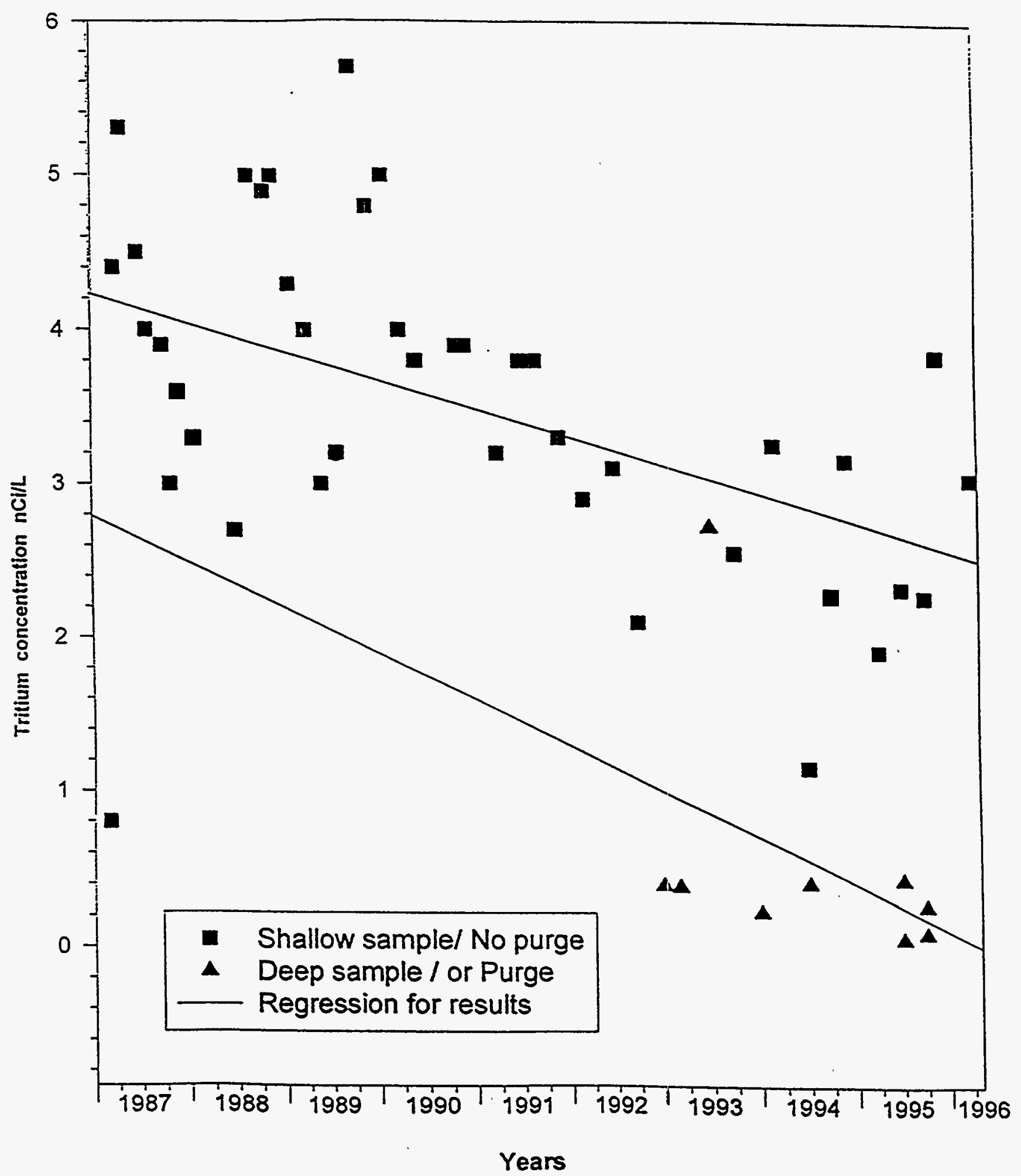

Figure 3.11 Tritium Concentrations in DH15, 1987-1995 
contamination. There are no USEPA drinking water limits or Illinois groundwater quality standards for either of these compounds.

\subsubsection{Well Water}

In July 1988, a well was installed in the Red Gate Woods picnic area (\#5160) to replace the existing well (\#5167) as a drinking water supply for visitors to this area. This is referred to as the Red Gate Woods North well (\#5160). This well was to be cased 20 feet into the dolomite to seal off fractures assumed to contain tritiated water. Previous experiments had indicated that the tritium moved at the till-dolomite interface and in the uppermost fractures in the dolomite. Extending the casing 20 feet into the dolomite and cementing the void between the casing and dolomite was expected to prevent tritium from entering the new well via these fractures. In addition, placement of a new pump mechanism on the new well was expected to eliminate the elevated lead concentrations found occasionally in the old well that resulted from corrosion of the old pump mechanism. The pump mechanism was removed from the old Red Gate Woods well to prevent its use by the public; however, the well was maintained as a sampling location for this monitoring program. In addition, the lower portion of the Red Gate Woods well (\#5167) was filled with grout to seal the lower fractures and prevent communication of water with the new well.

Sampling was conducted throughout the year at the forest preserve picnic wells located north of Plot $M$ and shown in Figure 1.2. These wells are located in the same dolomite as the previously discussed dolomite holes. Sampling from the well at 95th and Archer (\#5157) has not been conducted since 1992 nor will it be sampled in the future since this well was plugged by the Palos Forest Preserve. All the samples were analyzed for tritiated water and the results are listed in Table 3.12.

In late October, the Red Gate Woods Well (\#5167) was found to have been vandalized. A request was made of the Forest Preserve District of Cook County staff to arrange to have 
TABLE 3.12

Tritiated Water Content of Wells Near Site A/Plot M, 1995

(Concentrations in $\mathrm{nCi} / \mathrm{L}$ )

\begin{tabular}{|c|c|c|c|c|c|}
\hline $\begin{array}{l}\text { Date } \\
\text { Collected }\end{array}$ & $\begin{array}{l}\text { Red Gate } \\
\text { North } \\
5160\end{array}$ & $\begin{array}{c}\text { Red Gate } \\
5167\end{array}$ & $\begin{array}{c}\text { Opposite } \\
\text { Red Gate } \\
5159\end{array}$ & $\begin{array}{c}300 \text { yds. East } \\
\text { of Red Gate } \\
5158\end{array}$ & $\begin{array}{c}\text { Guard } \\
\text { Post } \\
5215\end{array}$ \\
\hline January 4 & 0.24 & $<0.1$ & 0.22 & $<0.1$ & $<0.1$ \\
\hline January 18 & 0.25 & $<0.1$ & 0.22 & - & - \\
\hline February 1 & 0.24 & $<0.1$ & 0.18 & $<0.1$ & $<0.1$ \\
\hline February 15 & 0.25 & $<0.1$ & 0.34 & - & - \\
\hline March 1 & 0.20 & $<0.1$ & 0.37 & $<0.1$ & $<0.1$ \\
\hline March 15 & 0.23 & $<0.1$ & 0.31 & - & - \\
\hline April 6 & 0.24 & $<0.1$ & 0.37 & $<0.1$ & $<0.1$ \\
\hline April 20 & 0.17 & $<0.1$ & 0.32 & - & - \\
\hline May 4 & 0.20 & $<0.1$ & 0.38 & $<0.1$ & $<0.1$ \\
\hline May 17 & 0.30 & $<0.1$ & 0.49 & - & - \\
\hline June 7 & 0.25 & $<0.1$ & 0.44 & $<0.1$ & $<0.1$ \\
\hline June 21 & 0.27 & $<0.1$ & 0.54 & - & - \\
\hline July 5 & 0.22 & $<0.1$ & 0.54 & 0.13 & $<0.1$ \\
\hline July 19 & 0.24 & $<0.1$ & 0.51 & - & - \\
\hline August 2 & 0.20 & $<0.1$ & 0.47 & $<0.1$ & $<0.1$ \\
\hline August 16 & 0.22 & $<0.1$ & 0.53 & - & - \\
\hline September 6 & 0.23 & $<0.1$ & 0.51 & $<0.1$ & $<0.1$ \\
\hline September 20 & 0.21 & $<0.1$ & 0.48 & - & - \\
\hline October 5 & 0.27 & $<0.1$ & 0.49 & 0.12 & $<0.1$ \\
\hline October 18 & 0.66 & $<0.1$ & 0.35 & - & - \\
\hline November 1 & 1.49 & Closed & 0.32 & $<0.1$ & $<0.1$ \\
\hline November 17 & 1.57 & Closed & 0.29 & - & - \\
\hline December 6 & 1.84 & Closed & 0.52 & $<0.1$ & $<0.1$ \\
\hline December 21 & 2.26 & Closed & 0.44 & - & - \\
\hline Average & 0.51 & $<0.1$ & 0.40 & $<0.1$ & $<0.1$ \\
\hline
\end{tabular}


the well repaired so that sampling could be conducted. Through a misunderstanding, the Forest Preserve District personnel closed and sealed the well. This involved filling the well with gravel and bentonite and welding a cover on the top as required by the State of Illinois well closure regulations. This well will no longer be available for sampling and has been removed from the schedule.

The tritium concentrations in wells \#5160 and \#5167 have decreased to the level where the earlier pattern of high concentrations in the winter and low concentrations in the summer is not readily detectable. This decrease over the past few years is illustrated in Figure 3.12, which is a plot of the tritium concentrations in wells \#5160, \#5167, and \#5159 for the past six years. The maximum tritium concentrations in the Red Gate Woods well (\#5167) dropped from $3.3 \mathrm{nCi} / \mathrm{L}$ in 1987 to $<0.1 \mathrm{nCi} / \mathrm{L}$ in 1995 , while the average concentration dropped from $1.6 \mathrm{nCi} / \mathrm{L}$ in 1987 to $<0.1 \mathrm{nCi} / \mathrm{L}$ in 1995 . The magnitude of the tritium concentrations in well \#5159 may be related to precipitation, with higher concentrations occurring during years of low rain. The average concentration in well \#5159 which decreased from $0.87 \mathrm{pCi} / \mathrm{L}$ in 1993 to $0.40 \mathrm{pCi} / \mathrm{L}$ in 1995 may also be related to the plugging of the lower fractures in DH 11 to 14.

The annual average tritium concentrations are slightly higher in the new well (\#5160) compared to the old well (\#5167), see Table 2.1. It is speculated that the higher concentrations of tritium in the Red Gate Woods North well (\#5160) compared to the Red Gate Woods well (\#5167) is due to the fact that it is drilled deeper and intercepts lower fractures in the dolomite that are connected to some of the dolomite holes near the intermittent stream, specifically DH 11 through DH 14. The other dolomite holes were not drilled deep enough to intercept this lower fracture. Flow in the dolomite holes is generally downward from the weathered zone to the bottommost fractures. Most of the flow exits the dolomite hole into the major fracture (96-98 feet below the surface), but some bypass it and flow also occurs at lower fractures (157 feet). This lower fracture is intercepted by well \#5160 but not \#5167 since this lower fracture (157 feet) was grouted in 1988. The upper fracture ( $96-98$ feet) has 


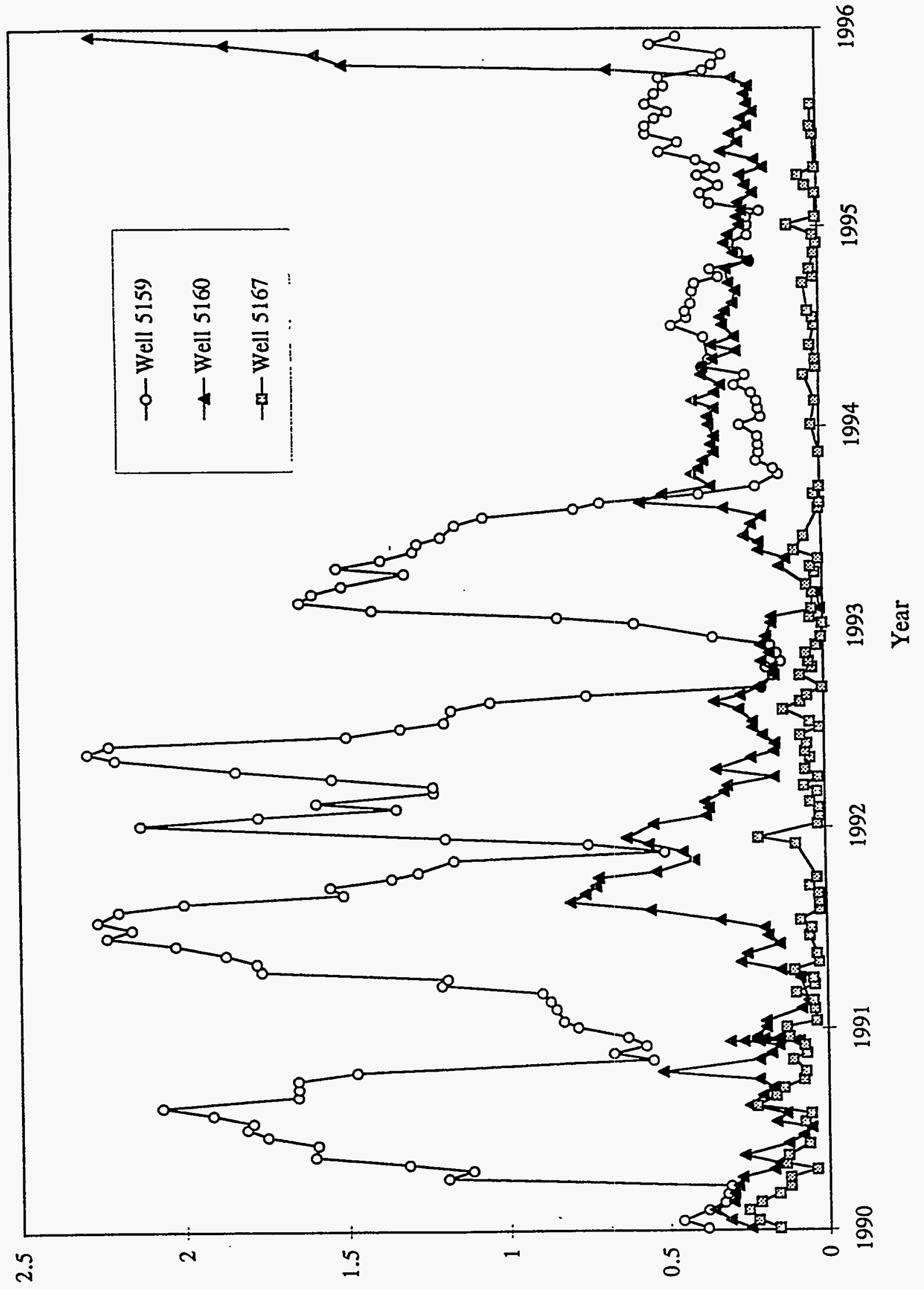

웅

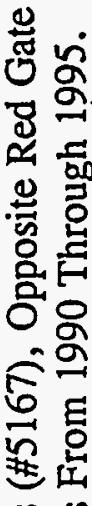

융

3

迥

요

幽

.$\Xi$

응

苋是

芯

记

ชั

过 胥

3 옥

马्व

氖

点

멈

T/Du u! suoṇenuวouo 
been cased off in \#5160. Therefore, the tritium present in the lower sections of the deepholes 11 to 14 moves through the lower fracture (157 feet) and is measured in well $\# 5160$. However, grouting the lower fractures in deep holes 11 to 14 in December 1993 did not result in any decrease in the tritium concentration in well \#5160. In fact, the tritium concentrations increased during the last two months of the year to greater than $2 \mathrm{nCi} / \mathrm{L}$. This was unexpected and no explanation is currently available.

The other wells, although also downgradient from Plot $M$, are evidently too far from the Plot to show measurable tritium concentrations. Two of the picnic wells, \#5159 and \#5158, were not available to the public during the year. The Forest Preserve District of Cook County had removed the pump handles due to high fecal coliform concentrations in the well water. A set of picnic well water samples was collected on April 28, 1995, and September 29, 1995, from the wells on the east and south sides of the Palos Forest Preserve. The sampled wells were \#5162, \#5031, \#5188, \#5153, \#5154, \#5226, \#5021, \#5193, \#5232, and \#5148 in Figure 1.2. All the tritium results were less than the detection limit of 0.1 $\mathrm{nCi} / \mathrm{L}$.

The Red Gate Woods North well (\#5160) is the location which provides the greatest potential radiation exposure to the public in 1995. If water equal to the Red Gate Woods North well average concentration of $0.51 \mathrm{nCi} / \mathrm{L}$ were the sole source of water for an individual, the annual dose from the tritium would be $0.023 \mathrm{mrem}$. If an individual consumed one liter of this water, the dose would be $3 \times 10^{-5}$ mrem.

In addition to tritiated water measurements, quarterly sets of water samples were collected from the picnic wells and analyzed for isotopic uranium. The uranium results are presented in Table 3.13. The range of concentrations is similar to that found previously and are consistent with concentrations of uranium found in well water away from Site A/Plot M. 
TABLE 3.13

Uranium Content of Well Water Near Plot M, 1995

(Concentrations in $\mathrm{pCi} / \mathrm{L}$ )

\begin{tabular}{llcccc}
\hline & & \multicolumn{4}{c}{ Date Collected } \\
\cline { 3 - 5 } $\begin{array}{l}\text { Well } \\
\text { Number* }\end{array}$ & Location & February 1 & May 4 & August 2 & November 1 \\
\hline 5160 & Red Gate Woods North & $0.12 \pm 0.08$ & $0.09 \pm 0.06$ & $0.05 \pm 0.05$ & $<0.01$ \\
5167 & Red Gate Woods & $0.04 \pm 0.06$ & $0.27 \pm 0.09$ & $0.07 \pm 0.06$ & - \\
5159 & $\begin{array}{c}\text { Opposite Entrance } \\
\text { to Red Gate Woods }\end{array}$ & $0.18 \pm 0.09$ & $0.05 \pm 0.06$ & $0.09 \pm 0.07$ & $0.03 \pm 0.06$ \\
& & & & & \\
\hline
\end{tabular}

*See Figure 1.2 
Samples were collected quarterly from the Red Gate Woods North well (\#5160) and analyzed for a number of inorganic constituents. The results are found in Table 3.14. Because this picnic well is used as a drinking water supply, the limits used were the State of Illinois concentrations of chemical constituents in drinking water. ${ }^{23}$ The constituents in Table 3.14 that do not have a specific limit are provided for completeness. Although the limits are exceeded for sulfate and manganese, this is probably due to natural levels. These concentrations are not unusual for dolomite water in northeast Illinois. Elevated levels of iron, lead, zinc, and some trace metals may be related to the decomposition of the well pump materials. There is no evidence that the source of the elevated inorganic constituents is from Plot M, since these metals are not found in the deepholes between Plot M and the Red Gate Woods wells. ${ }^{24}$

Four wells in private homes near 107th and Archer Avenue were sampled on April 5, 1995, and analyzed for gross alpha, gross beta, tritium, and gamma-ray-emitting radionuclides. These wells are in the same dolomite zone as the picnic wells. The gross alpha and gross beta activities were in the normal range of naturally-occurring radionuclides in groundwater. The gross alpha activities ranged from 2.2 to $4.0 \mathrm{pCi} / \mathrm{L}$ and the gross beta activities ranged from 8.2 to $10.9 \mathrm{pCi} / \mathrm{L}$. All the tritium results were less than the detection limit of $0.1 \mathrm{nCi} / \mathrm{L}$ and gamma-ray spectrometric analysis of the water did not detect any radionuclides associated with activities at Site $\mathrm{A} / \mathrm{Plot} \mathrm{M}$ above the detection limit of $1 \mathrm{pCi} / \mathrm{L}$. These results indicate that no radioactivity used or generated at Site $A / P l o t ~ M$ has entered this water system.

\subsection{Bottom Sediment}

Bottom sediment samples were collected from the stream next to Plot $\mathrm{M}$ at Location \#1 and Location \#9 on May 10, 1995, and on November 10, 1995 (see Figure 3.1). Various radiochemical analyses were performed on these samples and the results are found in Table 3.15. The results are similar for nearly all constituents except that cesium-137 and 
TABLE 3.14

Inorganic Constituents in Red Gate Woods North Well Water (\#5160), 1995 (Concentrations in $\mathrm{mg} / \mathrm{L}$ )

\begin{tabular}{|c|c|c|c|c|c|}
\hline $\begin{array}{l}\text { Inorganic } \\
\text { Constituent }\end{array}$ & February & May & August & November & Limit* \\
\hline Arsenic & $<0.0025$ & $<0.0025$ & $<0.0025$ & $<0.0025$ & 0.05 \\
\hline Barium & 0.019 & $<0.015$ & $<0.015$ & 0.019 & 1.0 \\
\hline Beryllium & $<0.0001$ & $<0.0001$ & $<0.0001$ & $<0.0001$ & - \\
\hline Cadmium & 0.0059 & 0.0022 & 0.0014 & 0.0019 & 0.01 \\
\hline Chloride & 206 & 172 & 175 & 115 & 250 \\
\hline Chromium & 0.001 & 0.010 & 0.010 & 0.006 & 0.05 \\
\hline Cobalt & $<0.025$ & $<0.025$ & $<0.025$ & $<0.025$ & - \\
\hline Copper & 0.95 & 0.92 & 3.48 & 0.06 & - \\
\hline Fluoride & 0.112 & 0.140 & 0.120 & 0.080 & - \\
\hline Iron & 113.2 & 77.3 & 60.4 & 9.8 & - \\
\hline Lead & 0.252 & 0.186 & 0.215 & 0.022 & 0.05 \\
\hline Manganese & 0.87 & 0.78 & 0.43 & 0.17 & 0.15 \\
\hline Mercury & $<0.0001$ & $<0.0001$ & $<0.0001$ & $<0.0001$ & 0.002 \\
\hline Nickel & $<0.04$ & $<0.04$ & $<0.04$ & $<0.04$ & - \\
\hline $\mathrm{pH}$ & 7.55 & - & - & 7.48 & - \\
\hline Silver & $<0.001$ & $<0.001$ & $<0.001$ & 0.0016 & 0.05 \\
\hline Sulfate & 608 & 445 & 366 & 731 & 250 \\
\hline Thallium & $<0.0015$ & $<0.0015$ & $<0.0015$ & $<0.0015$ & - \\
\hline Vanadium & $<0.055$ & $<0.055$ & $<0.055$ & $<0.055$ & - \\
\hline Zinc & 175.9 & 190.7 & 65.5 & 47.3 & - \\
\hline
\end{tabular}

${ }^{*}$ State of Illinois concentrations of chemical constituents in drinking water. ${ }^{23}$ See text. 
TABLE 3.15

Radioactivity Content of Streambed Next to Plot M, 1995

(Concentrations in $\mathrm{pCi} / \mathrm{g}$ )

\begin{tabular}{|c|c|c|c|c|}
\hline Radionuclide & $\begin{array}{l}\text { Date } \\
\text { Collected }\end{array}$ & $\begin{array}{l}\text { Location } \# 1^{*} \\
\text { (Upstream) }\end{array}$ & $\begin{array}{l}\text { Location \#9* } \\
\text { (Downstream) }\end{array}$ & $\begin{array}{l}\text { Ambient } \\
\text { Concentrations }\end{array}$ \\
\hline Potassium -40 & $\begin{array}{l}\text { May } 10 \\
\text { November } 10\end{array}$ & $\begin{array}{l}22.86 \pm 0.64 \\
23.94 \pm 0.66\end{array}$ & $\begin{array}{l}21.65 \pm 0.63 \\
22.41 \pm 0.64\end{array}$ & 11.1 \\
\hline Strontium-90 & $\begin{array}{l}\text { May } 10 \\
\text { November } 10\end{array}$ & $\begin{array}{l}0.10 \pm 0.01 \\
<0.1\end{array}$ & $\begin{array}{l}0.11 \pm 0.01 \\
0.10 \pm 0.01\end{array}$ & - \\
\hline Cesium-137 & $\begin{array}{l}\text { May } 10 \\
\text { November } 10\end{array}$ & $\begin{array}{l}0.18 \pm 0.02 \\
0.18 \pm 0.02\end{array}$ & $\begin{array}{l}0.36 \pm 0.02 \\
0.38 \pm 0.02\end{array}$ & 0.13 \\
\hline Radium-226 & $\begin{array}{l}\text { May } 10 \\
\text { November } 10\end{array}$ & $\begin{array}{l}1.43 \pm 0.06 \\
1.79 \pm 0.06\end{array}$ & $\begin{array}{l}1.73 \pm 0.06 \\
1.89 \pm 0.06\end{array}$ & 0.80 \\
\hline Thorium-228 & $\begin{array}{l}\text { May } 10 \\
\text { November } 10\end{array}$ & $\begin{array}{l}1.13 \pm 0.04 \\
1.30 \pm 0.04\end{array}$ & $\begin{array}{l}1.28 \pm 0.04 \\
1.36 \pm 0.04\end{array}$ & 0.65 \\
\hline Thorium-232 & $\begin{array}{l}\text { May } 10 \\
\text { November } 10\end{array}$ & $\begin{array}{l}0.93 \pm 0.08 \\
1.00 \pm 0.08\end{array}$ & $\begin{array}{l}1.03 \pm 0.08 \\
0.97 \pm 0.09\end{array}$ & 0.52 \\
\hline Uranium-234 & $\begin{array}{l}\text { May } 10 \\
\text { November } 10\end{array}$ & $\begin{array}{l}1.30 \pm 0.11 \\
1.36 \pm 0.13\end{array}$ & $\begin{array}{l}1.23 \pm 0.11 \\
1.32 \pm 0.12\end{array}$ & - \\
\hline Uranium-238 & $\begin{array}{l}\text { May } 10 \\
\text { November } 10\end{array}$ & $\begin{array}{l}1.39 \pm 0.12 \\
1.55 \pm 0.14\end{array}$ & $\begin{array}{l}1.31 \pm 0.11 \\
1.45 \pm 0.13\end{array}$ & - \\
\hline Plutonium-238 & $\begin{array}{l}\text { May } 10 \\
\text { November } 10\end{array}$ & $\begin{array}{l}0.0002 \pm 0.0003 \\
0.0005 \pm 0,0004\end{array}$ & $\begin{array}{l}0.0006 \pm 0.0004 \\
0.0004 \pm 0.0003\end{array}$ & 0.0001 \\
\hline Plutonium-239 & $\begin{array}{l}\text { May } 10 \\
\text { November } 10\end{array}$ & $\begin{array}{l}0.0077 \pm 0,0015 \\
0.0054 \pm 0.0013\end{array}$ & $\begin{array}{l}0.0270 \pm 0.0030 \\
0.0319 \pm 0.0035\end{array}$ & 0.0037 \\
\hline Americium-241 & $\begin{array}{l}\text { May } 10 \\
\text { November } 10\end{array}$ & $\begin{array}{l}0.0022 \pm 0.0007 \\
0.0023 \pm 0.0005\end{array}$ & $\begin{array}{l}0.0040 \pm 0.0008 \\
0.0040 \pm 0.0007\end{array}$ & 0.0019 \\
\hline
\end{tabular}

*See Figure 3.1. 
plutonium-239 are slightly elevated downstream. The concentrations are very low and in some cases similar to fallout levels of these radionuclides. For comparison to concentrations measured in the area away from the impact of any nuclear facilities, see the ANL-E Site Environmental Report for $1994 .^{25}$

\subsection{SUMMARY OF POTENTIAL RADIATION DOSE AND RISK ESTIMATES}

\subsection{Dose Estimates}

The dose to an individual exposed to radionuclides associated with Plot $\mathrm{M}$ can be estimated employing the DOE methodology for air, drinking water, and surface water discussed previously. If a hypothetical individual were exposed continuously to tritium at various locations near Plot $\mathrm{M}$, the dose could be estimated. Assuming a person breathed the air at Location \#9, drank water from Location \#9 or the seep (Location \#6), or drank water from Wells 5160 or 5167, the dose from exposure for all of 1995 at the maximum and annual average concentrations is collected in Table 4.1. This scenario assumes that the individual's sole source of air and water is at the identified location. In addition to the tritium dose, measurable concentrations of strontium-90, net of $0.25 \mathrm{pCi} / \mathrm{L}$ (see Table 3.3), exist at Location \#9. The dose from ingestion of strontium-90 at these concentrations is $0.02 \mathrm{mrem}$, a small fraction of the tritium dose. No strontium-90 was identified at any other of these locations.

A more meaningful estimation is for the occasional visitor to the Plot M area. Assuming a visitor spends one hour at Location $\# 9$ or drinks one liter of water from the surface stream or picnic wells, the dose from this exposure is estimated and presented in Table 4.2. The maximum total dose received by an occasional visitor is the combination of the separate pathways, breathing air at Location \#9 and drinking water from the Red Gate Woods North Well (5160). This maximum dose would be 0.00014 mrem per visit. 


\section{TABLE 4.1}

Dose From Continuous Exposure to Tritium at Selected Locations, 1995

\begin{tabular}{|c|c|c|c|c|c|}
\hline \multirow[b]{2}{*}{ Pathway } & \multicolumn{2}{|c|}{ Maximum } & \multicolumn{2}{|c|}{ Annual Avg. } & \multirow{2}{*}{$\begin{array}{c}\text { Average } \\
\text { Carcinogenic } \\
\text { Risk } \\
\end{array}$} \\
\hline & Conc. & Dose & Conc. & Dose & \\
\hline Air & $46.7 \mathrm{pCi} / \mathrm{m}^{3}$ & $0.025 \mathrm{mrem} / \mathrm{y}$ & $9.0 \mathrm{pCi} / \mathrm{m}^{3}$ & $0.005 \mathrm{mrem} / \mathrm{y}$ & $4 \times 10^{-9}$ \\
\hline \multicolumn{6}{|l|}{ Surface Water } \\
\hline Seep & $48.7 \mathrm{nCi} / \mathrm{L}$ & $\mathrm{mrem} / \mathrm{y}$ & $45.2 \mathrm{nCi} / \mathrm{L}$ & $2.1 \mathrm{mrem} / \mathrm{y}$ & $2 \times 10^{-6}$ \\
\hline Location \#9 & $13.5 \mathrm{nCi} / \mathrm{L}$ & $\mathrm{mrem} / \mathrm{y}$ & $10.6 \mathrm{nCi} / \mathrm{L}$ & $0.5 \mathrm{mrem} / \mathrm{y}$ & $4 \times 10^{-7}$ \\
\hline \multicolumn{6}{|l|}{ Well Water } \\
\hline $\begin{array}{l}\text { Red Gate Woods (5160) } \\
\text { Red Gate Woods (5167) }\end{array}$ & $\begin{aligned} & 2.26 \mathrm{nCi} / \mathrm{L} \\
< & 0.1 \mathrm{nCi} / \mathrm{L}\end{aligned}$ & $\begin{array}{r}0.104 \mathrm{mrem} / \mathrm{y} \\
<0.005 \mathrm{mrem} / \mathrm{y}\end{array}$ & $\begin{array}{r}0.51 \mathrm{nCi} / \mathrm{L} \\
<0.1 \mathrm{nCi} / \mathrm{L}\end{array}$ & $\begin{aligned} & 0.023 \mathrm{mrem} / \mathrm{y} \\
< & 0.005 \mathrm{mrem} / \mathrm{y}\end{aligned}$ & $\begin{array}{l}2 \times 10^{-8} \\
4 \times 10^{-9}\end{array}$ \\
\hline
\end{tabular}


TABLE 4.2

Estimates of Tritium Exposures to a Casual Visitor to Plot M, 1995

\begin{tabular}{|c|c|c|c|c|}
\hline Pathway & Quantity & Maximum Dose & Annual Average & $\begin{array}{c}\text { Average } \\
\text { Carcinogenic Risk }\end{array}$ \\
\hline Air & One Hour & $0.000003 \mathrm{mrem}$ & $0.0000005 \mathrm{mrem}$ & $10^{-12}$ \\
\hline \multicolumn{5}{|l|}{ Surface Water } \\
\hline Seep & One Liter & $0.003 \mathrm{mrem}$ & $0.003 \mathrm{mrem}$ & $10^{-9}$ \\
\hline Location \#9 & One Liter & $0.0008 \mathrm{mrem}$ & 0.0007 mrem & $10^{-9}$ \\
\hline \multicolumn{5}{|l|}{ Well Water } \\
\hline Red Gate Woods (5160) & One Liter & 0.00014 mrem & $0.00003 \mathrm{mrem}$ & $10^{-10}$ \\
\hline Red Gate Woods (5167) & One Liter & $<0.000007 \mathrm{mrem}$ & $<0.000007$ mrem & $<10^{-11}$ \\
\hline
\end{tabular}


In order to put the doses into perspective, comparisons can be made to annual average doses received by the public from natural or accepted sources of radiation. These are listed in Table 4.3. It is obvious that the magnitude of the doses potentially received near Plot $M$ from residual radioactive substances remaining from work conducted in this area are insignificant compared to these sources.

\subsection{Risk Estimates}

Risk estimates of possible health effects from radiation doses to the public from Plot $\mathrm{M}$ have been made to provide another perspective in interpreting the radiation doses. Estimated for carcinogenic risk, the risk of contracting cancer from these exposures, is included in Table 4.1 and Table 4.2 for the average exposure scenario. Based on the BIER V report, ${ }^{27}$ a dose of one mrem/y equates to an increased risk of $0.8 \times 10^{-6}$. This conversion ratio is used in these tables. The risks are estimated to be in addition to the normal incident rate of cancer in the general population. For example, a carcinogenic risk of $10^{-7}$ would mean one additional cancer to 10,000,000 people exposed under the prescribed conditions. The EPA environmental protection standards are generally based on an acceptable risk between $10^{-4}$ and $10^{-6}$. This would imply that a risk of greater than $10^{-4}$ would be unacceptable and a risk of less than $10^{-6}$ would be acceptable.

Examination of Table 4.1 indicates that even under the very conservative assumptions of sole source use of the air and water at Plot $\mathrm{M}$ annual average concentrations, the risk is less than the EPA recommendation. For the combined hypothetical dose to an occasional visitor of $0.00002 \mathrm{mrem}$, the risk would be about $10^{-10}$. The risk from exposure to radionuclides at Plot $\mathrm{M}$ can be compared to the risk associated with natural events. A few examples are collected in Table 4:4. The risk from the naturally-occurring sources of radioactivity listed in Table 4.3 is estimated to be about one additional cancer in a population of 8000 . Therefore, the monitoring program results have established that radioactivity at 
TABLE 4.3

Annual Average Dose Equivalent in the U. S. Population ${ }^{*}$

\begin{tabular}{|c|c|}
\hline Source & (mrem) \\
\hline $\begin{array}{l}\text { Natural Sources } \\
\text { Radon } \\
\text { Internal }\left({ }^{40} \mathrm{~K} \text { and }{ }^{226} \mathrm{Ra}\right) \\
\text { Cosmic } \\
\text { Terrestrial }\end{array}$ & $\begin{array}{r}200 \\
39 \\
28 \\
28\end{array}$ \\
\hline $\begin{array}{l}\text { Medical } \\
\text { Diagnostic X-rays } \\
\text { Nuclear Medicine }\end{array}$ & $\begin{array}{l}39 \\
14\end{array}$ \\
\hline $\begin{array}{l}\text { Consumer Products } \\
\text { Domestic Water Supplies, } \\
\text { Building Materials, etc. }\end{array}$ & 10 \\
\hline $\begin{array}{l}\text { Occupational (medical } \\
\text { radiology, industrial } \\
\text { radiography, research, etc.) }\end{array}$ & 1 \\
\hline Nuclear Fuel Cycle & $<1$ \\
\hline Fallout & $<1$ \\
\hline Other Miscellaneous Sources & $<1$ \\
\hline Total & 360 \\
\hline
\end{tabular}

${ }^{*}$ NCRP Report No. $93 .^{26}$ 
Plot $M$ is very low and does not endanger the health or safety of those living in the area or visiting the site.

\section{TABLE 4.4}

Risk of Death From Natural Events

\begin{tabular}{ll}
\hline \multicolumn{1}{c}{ Cause } & \multicolumn{1}{c}{ Risk } \\
\hline Struck by Lightning & $5 \times 10^{-8}$ \\
Tornado & $1 \times 10^{-7}$ \\
Flood & $1 \times 10^{-7}$ \\
Hurricane & $2.5 \times 10^{-7}$ \\
Drowning & $8 \times 10^{-6}$ \\
Air Travel & $3 \times 10^{-6}$ \\
Firearms & $2 \times 10^{-6}$ \\
\hline
\end{tabular}




\subsection{REFERENCES}

1. Golchert, N. W. and Sedlet, J., Formerly Utilized MED/AEC Sites Remedial Action Program - Radiological Survey of Site A, Palos Park Forest Preserve, Chicago, Illinois, U. S. Department of Energy Report DOE/EV-0005/7 (April 1978).

2. Golchert, N. W., Sedlet, J., and Hayes, K. A., Environmental Surveillance of the Palos Park Forest Preserve, U. S. Department of Energy Report ANL-83-6 (January 1983).

3. Golchert, N. W. and Sedlet, J., Site Surveillance and Maintenance Program for Palos Park Report for 1982, Argonne National Laboratory (available from the authors) (April 1984).

4. Golchert, N. W. and Sedlet, J., Site Surveillance and Maintenance Program for Palos Park Report for 1983, Argonne National Laboratory (available from the authors) (June 1984).

5. Golchert, N. W. and Sedlet, J., Site Surveillance and Maintenance Program for Palos Park Report for 1984, Argonne National Laboratory (available from the authors) (April 1985).

6. Golchert, N. W. and Sedlet, J., Site Surveillance and Maintenance Program for Palos Park Report for 1985, U. S. Department of Energy Report ANL-86-25 (April 1986).

7. Golchert, N. W., Site Surveillance and Maintenance Program for Palos Park - Report for 1986, U. S. Department of Energy Report ANL-87-8 (April 1987).

8. Golchert, N. W., Site Surveillance and Maintenance Program for Palos Park - Report for 1987, U. S. Department of Energy Report ANL-88-12 (April 1988).

9. Golchert, N. W., Site Surveillance and Maintenance Program for Palos Park - Report for 1988, U. S. Department of Energy Report ANL-89/7 (April 1989). 
10. Golchert, N. W., Surveillance of Site A and Plot M - Report for 1989, U. S. Department of Energy Report ANL-90/7 (April 1990).

11. Golchert, N. W., Surveillance of Site A and Plot $M$ - Report for 1990, U. S. Department of Energy Report ANL-91/2 (May 1991).

12. Golchert, N. W., Surveillance of Site A and Plot M-Report for 1991; U. S. Department of Energy Report ANL-92/13 (May 1992).

13. Golchert, N. W., Surveillance of Site A and Plot $M$ - Report for 1992, U. S. Department of Energy Report ANL-93/4 (May 1993).

14. Golchert, N. W., Surveillance of Site A and Plot M - Report for 1993, U. S. Department of Energy Report ANL-94/9 (May 1994).

15. Golchert, N. W., Surveillance of Site A and Plot M - Report for 1994, U. S. Department of Energy Report ANL-95/7 (May 1995).

16. U. S. Department of Energy, "Radiation Protection of the Public and the Environment," DOE Order 5400.5, February 8, 1990.

17. 'U. S. Environmental Protection Agency, "National Primary Drinking Water Regulations," 40 CFR Part 141, Federal Register, 50, pp. 46900, November 13, 1985.

18. U. S. Department of Energy, "Environmental Regulatory Guide for Radiological Effluent Monitoring and Environmental Surveillance," DOE/EH-0173T, January 1991.

19. Golchert, N. W., Duffy, T. L., and Moos, L. P., Argonne National Laboratory-East Site Environmental Report for Calendar Year 1990, U. S. Department of Energy Report ANL91/3 (July 1991). 
20. International Commission on Radiological Protection, "Reference Man: Anatomical, Physiological, and Metabolic Characteristics," ICRP Publication 23, Pergamon Press, New York, NY (1975).

21. U. S. Department of Energy, "Internal Dose Conversion Factors for Calculation of Dose to the Public," DOE/EH-OO71, July 1988.

22. Nicholas, J. R. and Healy, R. W., "Tritium Migration From a Low-Level RadioactiveWaste Disposal Site Near Chicago, Illinois, " U. S. Geological Survey Water-Supply Paper 2333, 1988.

23. State of Illinois, Rules and Regulations, Title 35, Environmental Protection, Subtitle C; Section 302.304, Chemical Constituents, March 22, 1985.

24. Final report - Tritium Migration and Hydrogeological Studies in the Vicinity of Plot $M$ Palos Forest Preserve, International Technology Corporation Report, Project No. 313433, August 1994.

25. Golchert, N. W. and Kolzow, R. G., Argonne National Laboratory-East Site Environmental Report for Calendar Year 1994, U. S. Department of Energy Report ANL-95/8 (May 1995):

26. National Council on Radiation Protection and Measurements, Ionizing Radiation Exposure of the Population of the United States, NCRP Report No. 93, September 1, 1987.

27. Committee on Biological Effects of Ionizing Radiation, Health Effects on Populations of Exposure to Low Levels of Ionizing Radiation - BEIR V Report, National Academy Press, Washington, 1990. 


\subsection{APPENDICES}

\subsection{Quality Assurance Program}

All nuclear instrumentation is calibrated with standardized sources obtained from or traceable to the U. S. National Institute of Standards and Technology (NIST). The equipment is checked prior to the sample measurements with secondary counting standards to insure proper operation. Samples were periodically analyzed in duplicate or with the addition of known amounts of a radionuclide to check precision and accuracy. Intercomparison samples distributed by the DOE Environmental Measurements Laboratory Quality Assurance Program, a semi-annual distribution of four different sample matrices containing various combinations of radionuclides are analyzed. The results of our participation in this program for 1994 are published in ANL-95/8. ${ }^{25}$

Many factors enter into an overall quality assurance program other than the analytical quality control discussed above. Representative sampling is of prime importance. Appropriate sampling protocols are followed for each type of sampling being conducted. Water samples are pre-treated in a manner designed to maintain the integrity of the analytical constituent. For example, samples for trace radionuclide analyses are acidified immediately after collection to prevent hydrolytic loss of metal ions and filtered to reduce leaching from suspended solids.

The monitoring wells are sampled using the protocols listed in the Resource Conservation and Recovery Act (RCRA) Groundwater Monitoring Technical Enforcement Guidance Document. The volume of water in the casing is determined by measuring the water depth from the surface and the depth to the bottom of the well. This latter measurement also determines whether siltation has occurred that might restrict water movement in the screen area. For those wells in the glacial till that do not recharge rapidly, the well is emptied and the volume removed compared to the calculated volume. In most cases, these volumes are nearly identical. The well is then sampled by bailing with a Teflon bailer. If samples for parameters such as priority pollutants are collected, field parameters for these samples ( $\mathrm{pH}$, specific conductance, redox potential, and temperature) 
are measured per well volume while purging. Most samples are collected for radiological analyses only. No field parameters are measured for these samples. For samples in the porous, saturated zone which recharge rapidly, three well volumes are purged using submersible pumps. If field parameters are measured, samples are collected as soon as these readings stabilize. All samples are placed in precleaned bottles, labeled, and preserved. All field measurement and sampling equipment are cleaned by field rinsing with Type II deionized water. The samples are transferred to the analytical laboratory using a computer floppy disk which generates a one-page list of all samples. This list acts as the chain-of-custody transfer document.

\subsection{Applicable Standards}

The standard that is relevant to this study is the DOE Order 5400.5 which established a dose limit of $100 \mathrm{mrem} / \mathrm{y} .{ }^{16}$ The dose limit and dose calculation methodology is applicable to all media: air, surface water, deep holes, boreholes, and drinking water. The EPA drinking water standard ${ }^{17}$ is not applicable to the picnic wells since they do not meet the definition of a public water system. However, the EPA standard of $20 \mathrm{nCi} / \mathrm{L}$ for tritium may be useful for some comparison purposes.

\subsection{Analytical Methods}

The analytical methods used to obtain the data in this report are the same as those described in ANL-95/8. ${ }^{25}$

\subsection{Acknowledgments}

The analytical separations and radiochemical measurements were conducted by the Dosimetry and Analytical Services Section of the ESH Division. Sample collection and field measurements were conducted by Michael Cole, Noel Feeney, Rob Piorkowski, and Keith Trychta of the EMO Monitoring and Surveillance Group. Most of the figures and tables were prepared by Edyta 
Betlej and Michael Skwarek who are parallel co-op students within EMO under the direction of Dolores M. Ray. The dedicated effort of Rita M. Beaver (EMO), who typed and prepared this manuscript is greatly appreciated. A draft of this report was reviewed by members of the ANL and DOE staff, who made a number of constructive comments. Funding to support this program was provided by the Environmental Management Program through the U. S. Department of Energy-Chicago Operations Office. 
Distribution for ANL-96/2

Internal

M. C. Cole

R. F. Coley

N. Feeney

N. W. Golchert (50)

J. E. Helt

M. A. Kamiya

R. G. Kolzow

W. D. Luck

L. P. Moos

D. M. Nelson

C. A. Osolin

R. E. Piorkowski

D. M. Ray

J. Sedlet

R. J. Teunis

C. E. Till

R. A. Wynveen

TIS File

\section{External}

DOE OSTI, for distribution per UC-511 (97)

ANL-E Library

ANL-W Library, AW-IS

C. Langenfeld, Manager, DOE Chicago Operations Office

S. Nielson; DOE Chicago Operations Office (50)

B. J. Quirke, DOE Chicago Operations Office

S. Robison, DOE Headquarters (EM-44)

R. Allen, Mlinois Department of Nuclear Safety

J. Barnett, U. S. Environmental Protection Agency, Region V

Bedford Park Public Library

Bridgeview Public Library

E. Formento, Mayor of Willow Springs

T. Hyde, U. S. Environmental Protection Agency

T. Kelleher, Chicago District, Corps of Engineers

C. Lagges, Cook County Department of Environmental Control

R. LaMort, Cook County Board of Commissioners

Librarian, Illinois Department of Nuclear Safety

A. Martin, Jr., U. S. Geological Survey

M. McMullan, U. S. Environmental Protection Agency, Environmental Review Branch 
C. Merenowicz, Forest Preserve District of Cook County

P. Mills, U. S. Geological Survey

J. R. Nicholas, U. S. Geological Survey

T. Ortciger, Illinois Department of Nuclear Safety

L. Regner, U. S. Environmental Protection Agency, Federal Facility Coordinator

S. Shemanski, Cook County Department of Public Health

C. Smith, Illinois Environmental Protection Agency

D. Weber, Forest Preserve District of Cook County

R. Wollschlager, Cook County Department of Public Health 


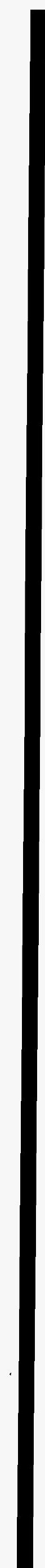

